
237-251. https://doi.org/10.1016/j.foreco.2015.12.033

This manuscript version is made available under the CC-BY-NC-ND 4.0 1icense http://creativecommons.org/1icenses/by-nc-nd/4.0/

\title{
Patterns of mast fruiting of common beech, sessile and common oak, Norway spruce and Scots pine in Central and Northern Europe
}

Anita Nussbaumer ${ }^{*}$, Peter Waldner ${ }^{1}$, Sophia Etzold ${ }^{1}$, Arthur Gessler ${ }^{1,2}$, Sue Benham ${ }^{3}$, Iben Margrete Thomsen $^{4}$, Bruno Bilde Jørgensen ${ }^{4}$, Volkmar Timmermann ${ }^{5}$, Arne Verstraeten ${ }^{6}$, Geert Sioen ${ }^{6}$, Pasi Rautio $^{7}$, Liisa Ukonmaanaho ${ }^{7}$, Mitja Skudnik ${ }^{8}$, Vladislav Apuhtin ${ }^{9}$, Sabine Braun ${ }^{10}$, Alexandra Wauer $^{11}$

${ }^{1}$ Swiss Federal Institute for Forest, Snow and Landscape Research WSL, Birmensdorf, Switzerland

${ }^{2}$ Leibniz Centre for Agricultural Landscape Research (ZALF), Müncheberg, Germany

${ }^{3}$ Forest Research, Alice Holt, Farnham, UK

${ }^{4}$ Department of Geosciences and Natural Resource Management, University of Copenhagen, Denmark

${ }^{5}$ Norwegian Institute of Bioeconomy Research (NIBIO), Aas, Norway

${ }^{6}$ Research Institute for Nature and Forest (INBO), Brussels, Belgium

${ }^{7}$ Natural Resources Institute Finland, Finland

${ }^{8}$ Department of Forest and Landscape Planning and Monitoring, Slovenian Forestry Institute, Ljubljana, Slovenia

${ }^{9}$ Estonian Environment Agency, Tartu, Estonia

${ }^{10}$ Institute for Applied Plant Biology (IAP), Schönenbuch, Switzerland

${ }^{11}$ Bayrische Landesanstalt für Wald und Forstwirtschaft, Freising, Germany

*Corresponding author

Anita Nussbaumer

Swiss Federal Institute for Forest, Snow and Landscape Research WSL

Long-term Forest Ecosystem Research Programme LWF

Zürcherstrasse 111

CH-8903 Birmensdorf

Switzerland

Tel. +41447392869

Email: anita.nussbaumer@wsl.ch 


\begin{abstract}
Occurrence of mast years, i.e. the synchronous production of vast amounts of fruits or seeds, has an important impact on forest ecosystems, their functioning and their services. We investigated the mast patterns of the forest tree species common beech, common and sessile oak, Norway spruce and Scots pine in Central and Northern Europe over the last two to three decades. We analysed data from the International Co-operative Programme on Assessment and Monitoring of Air Pollution Effects on Forests (ICP Forests) and additional Danish, German, Flemish and Swiss datasets.

Within-plot synchrony of fructification intensity in individual trees was high in beech and spruce and lower in oak species and pine. Mast frequency increased in most regions for beech, whereas the other species showed mixed or no trends. Beech, oak species and spruce showed strong mast year (MY) synchrony, but pine did not. MY synchrony between species was only significant in Bavaria, in Switzerland and between beech, oak species and spruce in Denmark. The deciduous species showed bimodal normal masting, while the conifers had switching normal masting. Oak species and the conifers supported the large seed and the accessory costs hypotheses, and beech and spruce supported the economy of scale, predator satiation and resource allocation hypotheses.
\end{abstract}

Keywords: mast seeding, large seed hypothesis, accessory costs hypothesis, economy of scale hypothesis, predator satiation hypothesis, resource allocation hypothesis.

Abbreviations: BW: Baden-Württemberg, Germany, BY: Bavaria, Germany, NRW: North RhineWestphalia, Germany, CH1: ICP Forests Level I dataset in Switzerland, CH2: additional Swiss data from WSL, CH3: additional Swiss data from IAP, EOS: economy of scale hypothesis, FY: fruiting year, MF: mast frequency, MY: mast year, $\mathrm{MY}_{\text {plot: }}$ mast year on plot level, $\mathrm{MY}_{\text {region}}$ : regional mast year 


\section{Introduction}

Mast seeding is the phenomenon of plant populations producing abundant seed quantities, which exceed the average amount of seeds in a flowering year (Herrera et al., 1998; Kelly, 1994; Kelly and Sork, 2002; Nilsson and Wastljung, 1987). This behaviour is mostly seen in trees above 30-50 years (Rohmeder, 1972). The occurrence of mast seeding/mast fruiting was identified for many forest tree species in the second half of the $19^{\text {th }}$ century (Beling, 1877; Lauprecht, 1875; Schwappach, 1895). The irregular occurrence of high amounts of seeds/fruits on a stand-wise level was first thought to be triggered by resource matching, described as the production of seeds and fruits if the circumstances are beneficial for investing resources into reproduction rather than growth (Büsgen and Münch, 1929). Kelly (1994) described mast years (MY) as a regional phenomenon and therefore, the term mast "sensu stricto" cannot be applied to single trees. In literature, there are various definitions of MY in use. In many studies, MY definition is derived from quantitative data like litterfall biomass measurements (Curran et al., 1999; Greene and Johnson, 2004; Koenig et al., 1994; LaMontagne and Boutin, 2009; McKone et al., 1998; Peters et al., 2005). Although masting is thought to be an important survival strategy, not all tree species show this behaviour. Studies have shown that masting can occur super-regional or even on a continental scale and can also cross species boundaries (Koenig and Knops, 2000). To investigate the nature of masting patterns, Kelly (1994) proposed a classification into three categories: putative, strict and normal mast behaviour. Putative masting is triggered only by environmental causes, while strict masting shows bimodality between years with no seeds/fruits and years with abundant seeds/fruits. Most species however show normal fruiting, including the analysed species in this study, Fagus sylvatica L. (common or European beech), Quercus robur L. (common oak) and Quercus petraea (Matt.) Liebl. (sessile oak), Picea abies (L.) Karst. (Norway spruce) and Pinus sylvestris L. (Scots pine), and show patterns of low and high fruiting years with absence of years with no seed or fruit production (Broome et al., 2007; Crawley and Long, 1995; Lindquist, 1931). Kelly (1994) distinguished two types of normal masting described by bimodal and switching normal masting. He defined bimodal normal masting to have a similar pattern as strict masting, but with possible low level of seed/fruit production in non-MY. In contrast, switching normal masting was described as a variation of seed quantities per year but without a bimodal pattern where MY cannot be recognised on stand level (Kelly, 1994).

In recent studies an increase in MY frequency has been observed (Overgaard et al., 2007; Paar et al., 2011). Potential causes for this increase are rising temperatures during the vegetation period, a change in precipitation and water availability, a change in nitrogen deposition, increasing atmospheric carbon dioxide levels or a general change in management and therefore an increase in available nutrients (Overgaard et al., 2007; Paar et al., 2011; Solberg et al., 2009). However, Hoch et al. (2003) supposed 
that carbon availability is not a limitation factor for seed production. Mast events have a relevant impact in different fields, such as agriculture, forestry and ecosystem science. A deeper knowledge about the mechanisms triggering mast behaviour is therefore crucial e.g. for sustainable forest management.

In forestry, MY are important for natural forest regeneration and have an impact on timber production because growth has been found to be lower in MY (Drobyshev et al., 2010; Eichhorn et al., 2008). The effect of MY on wildlife was studied for many species, among them birds, rodents and deer (Jenni, 1987; McKone et al., 1998; McShea, 2000; Picard et al., 1991; Schnurr et al., 2002; Selås, 1997; Tachiki and Iwasa, 2013). Jenni (1987) found that bramblings (Fringilla montifringilla L.) shift their hibernation locations northwards after beech MY, and Picard et al. (1991) found that corn consumption in red deer (Cervus elaphus L.) decreased considerably after oak MY. MY can also influence pest and disease occurrence by controlling zoonosis carrier populations and thus problematic diseases such as Lyme disease and Hanta viruses (Ostfeld, 2013; Vapalahti et al., 2003).

Today, several theories for MY occurrence are discussed, both evolutionary and mechanistic. Whilst masting has been the object of many studies, there is no consensus on the ultimate evolutionary cause for mast behaviour (Kelly and Sork, 2002; Silvertown, 1980). Evolutionary hypotheses include

resource allocation (or depletion) hypothesis (Büsgen and Münch, 1929; Kelly, 1994; Kelly and Sork, 2002)

economy of scale hypothesis (EOS) in regard to pollination efficiency (Kelly, 1994; Kelly and Sork, 2002; Kon et al., 2005a; Smith et al., 1990)

predator satiation hypothesis (Kelly, 1994; Kelly and Sork, 2002; Kon et al., 2005a)

accessory costs hypothesis (Kelly, 1994)

large seed hypothesis (Kelly, 1994).

The resource allocation hypothesis describes the behaviour of investment in fruit production if resources are available and lead to a mast failure due to resource depletion in the wake of a MY (Janzen, 1971). The EOS states that it is advantageous for trees in a stand to invest in coordinated periodic large flowering efforts to enhance the success of wind pollination (Kelly, 1994). Saturation of predator populations through high fruit production will lead to a higher survival rate in seed (predator satiation hypothesis, Kelly (1994) and Kon et al. (2005b)). The accessory costs hypothesis indicates that it is not favourable for trees to have low fruit production as the additional costs for 
reproduction are large (Kelly, 1994). If a species produces large seeds (large seed hypothesis) resource recovery will lead to years of mast failure after a MY (Kelly, 1994). The accessory costs hypothesis and the large seed hypothesis do not require synchronised fruit production and thus do not explain MY occurrence. Nevertheless, these two hypotheses are worth to be considered as an explanation for fruiting occurrence (Kelly, 1994).

In contrast to evolutionary theories about mast behaviour, mechanistic theories discuss the preconditions for MY and propose, among other factors, an influence of weather conditions in the preceding growing period of a MY and the florescence period in the actual MY, as well as the fruiting level of the preceding year (Gurnell, 1993; Kon et al., 2005b; Overgaard et al., 2007).

Although there are several studies from European countries and regions about masting in forest tree species and its drivers, comparisons between different regions are rare. Furthermore, the acquisition of comparable data is challenging. In this study, we primarily investigated the data set of the crown condition survey from the International Co-operative Programme on Assessment and Monitoring of Air Pollution Effects on Forests (ICP Forests). In this frame tree vitality has been monitored on a network of plots on a grid of $16 \times 16 \mathrm{~km}^{2}$ since the mid-1980s using harmonised methods (Eichhorn et al., 2010). Tree-wise assessment of fruiting intensity has only been introduced as parameter of the crown condition assessment in 2007. However, it had been assessed earlier by several countries. As an extension of the ICP Forests dataset we included additional data from Switzerland, Denmark, Flanders (Belgium) and the federal state of Baden-Württemberg (Germany) with regard to fruit and/or seed production. These data were collected on a stand-wise level with methods similar to the ICP Forests crown condition assessment (stands will be called plots hereafter). In our study, we analysed the masting behavior of common beech (in short: beech), sessile and common oak (oak species), Norway spruce (spruce) and Scots pine (pine) in eight Central and Northern European regions.

The objective of this study was to answer the following questions:

How can MY be defined on plot and regional level via tree-wise data?

Have there been temporal trends in MY frequency in the last two to three decades in the investigated Central and Northern European regions?

How synchronous is mast fruiting within and between species on plot and regional level?

Do possible spatio-temporal trends in masting behavior give support to the hypotheses presented above? 
In order to find answers to these questions we first defined MY in the ICP Forests crown condition dataset and in the additional datasets. Secondly, we checked if there were spatio-temporal patterns of synchrony in mast behaviour in different regions.

\section{Material and methods}

\subsection{ICP Forests plot network and additional datasets}

The geographical extent of the data from the ICP Forests Level I network covers large parts of Europe from $-5^{\circ}$ to $30^{\circ} \mathrm{E}, 40^{\circ}$ to $70^{\circ} \mathrm{N}$ and an altitudinal range of $0 \mathrm{~m}$ to $2000 \mathrm{~m}$ above sea level. Climatic conditions include temperate, continental, maritime, alpine and Mediterranean climates, with a range of mean temperatures between $-4.5^{\circ} \mathrm{C}$ and $18.4^{\circ} \mathrm{C}$. Annual precipitation rates range from 68 to 4900 $\mathrm{mm}$. In the ICP Forests crown condition survey tree vitality assessments are carried out with harmonised methods (Eichhorn et al., 2010) and include assessments of defoliation, damage causes, fruiting and mortality as well as morphology and apical shoot architecture at tree level (Eichhorn et al., 2010). Parameters are assessed annually and intercalibration courses for Nordic, Central Europe and Mediterranean regions (Eichhorn et al., 2010) with a training for the field observers are held before each survey at national level. For a description of the additional datasets from Switzerland, Denmark, Flanders and Baden-Württemberg see Appendix.

In our study, we investigated the temporal variation in mast behaviour in beech, oak, spruce and pine species. The two oak species common and sessile oak were analysed together as they regularly hybridise (Muir et al., 2000). As we investigated long-term patterns plots with less than eight consecutively assessed years were excluded. For the definition of MY on plot level we included only plots with a minimum of 10 assessed individuals per tree species. These restrictions led to a dataset which covered Norway, Estonia, Denmark, Great Britain, Belgium (Flanders), Germany (North Rhine-Westphalia (NRW), Baden-Württemberg (BW), Bavaria (BY)) and Switzerland (CH1-CH3). $\mathrm{CH} 1$ is the ICP Forest dataset, $\mathrm{CH} 2$ a dataset on masting in selected stands from WSL with additional data from the principality of Liechtenstein and $\mathrm{CH} 3$ a dataset from permanent plots assessed by the Institute for Applied Plant Biology (IAP) (see Appendix). As Norway has a wide north-south range we split this dataset into two subgroups, south and north of $61.5^{\circ} \mathrm{N}$. The maximum time span of the different datasets can be seen in table 1, and the spatial distribution is represented in fig. 1. Detailed information can be found in the species-wise maps in the Appendix (fig. A1-A4). The number of plots used in the different analyses varied depending on the requirements. 


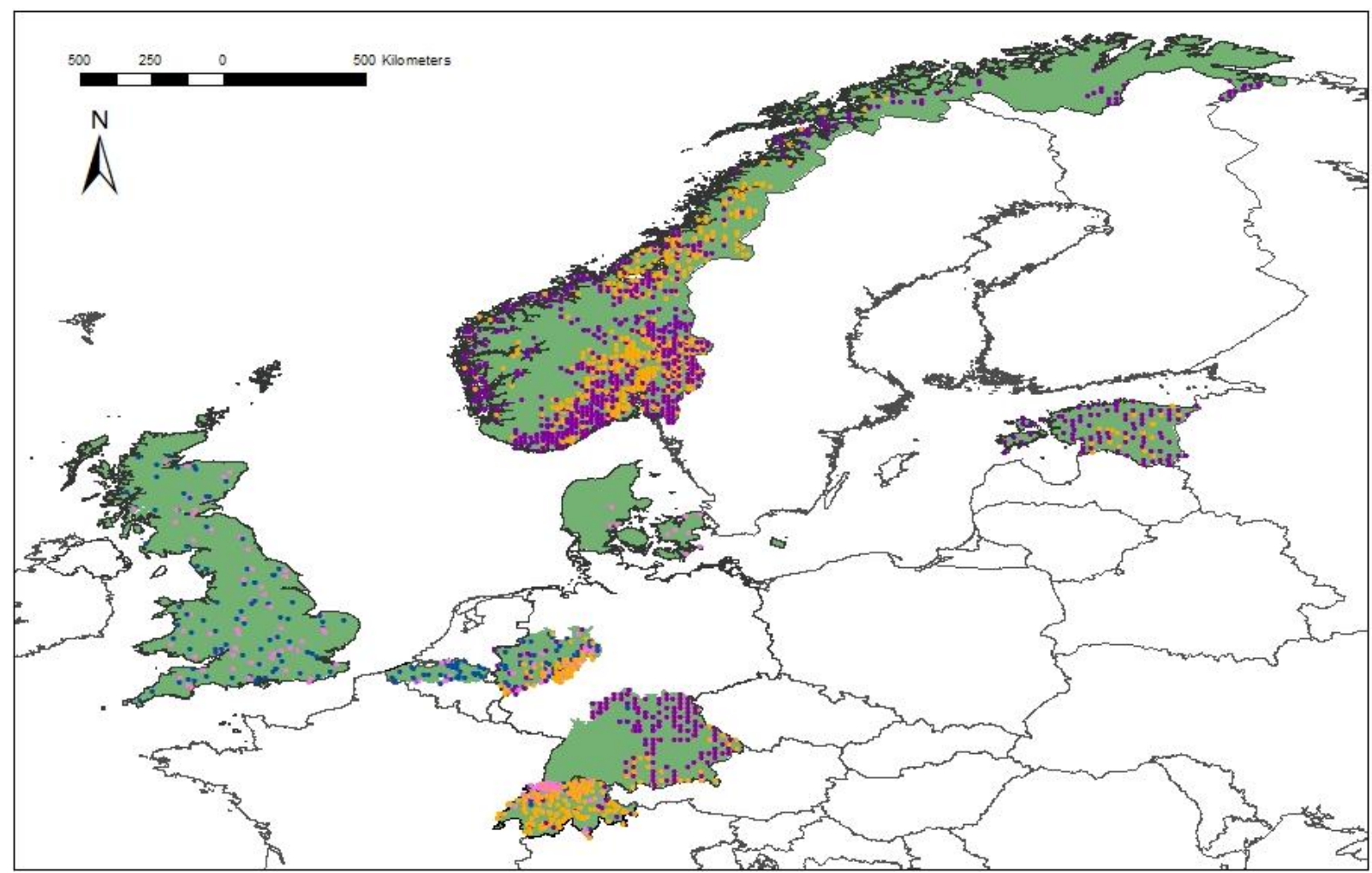

Fig. 1: Overview of analysed plots and regions. Pink=beech, blue=oak, orange $=$ spruce, purple=pine, green areas: covered by the analyses (locations of plots in Denmark, Baden-Württemberg and Bavaria partly not shown).

Table 1: List of the assessed time periods per country and species from all datasets.

\begin{tabular}{lcccc}
\hline Dataset & Beech & Oak & Spruce & Pine \\
\hline Great Britain & $1989-2006$ & $1989-2007$ & & \\
Flanders & $2004-2014$ & $2004-2014$ & & \\
Switzerland CH1 & & & $1985-1996$, & \\
Switzerland CH2 & & & $2006-2013$ & \\
Switzerland CH3 & $2001-2013$ & & $1985-2013$ & \\
North Rhine-Westphalia & $1986-2011$ & & $1986-2011$ & \\
Baden-Württemberg & $1995-2013$ & $1995-2013$ & $1995-2013$ & \\
Bavaria & $1995-2013$ & $1995-2013$ & $1995-2013$ & $1995-2013$ \\
Denmark & $1999-2008$ & $1999-2008$ & $1999-2008$ & $1999-2008$ \\
Estonia & $1989-2013$ & $1995-2013$ & $1995-2013$ & $1995-2013$ \\
Norway & & & $1995-2012$ & $1994-2011$ \\
\hline
\end{tabular}




\subsection{Observation method}

Since 2007, the ICP Forests crown condition survey carried out tree-wise assessment on the Level I plot network (16x16 km² grid), including the qualitative parameter of visual assessment on the fruiting intensity per vegetation period (Eichhorn et al., 2010). For pine, only the green cones from the preceding year were assessed. Fruiting intensity was assessed using four classes. No fruiting refers to trees with total absence of fruits. Scarce fruiting is defined as not noticeable at first sight and only visible with binoculars. Common fruiting can be recognized by the naked eye, whereas abundant fruiting is obvious and determines the appearance of the tree. These four classes are encoded in 3 categories in the dataset $(1=$ absent, scarce fruiting, $2=$ common fruiting, 3 = abundant fruiting). In the additional dataset from WSL $(\mathrm{CH} 2)$ and Baden-Württemberg $(\mathrm{BW})$ the fruiting intensity was assessed on stand level regarding economy of seed harvesting for seed production and adjusted to a corresponding 3 category scale similar to the ICP Forests categories. The datasets from IAP (CH3) and from Denmark (DK) were in a different format and their inclusion will be explained in the next chapter.

\subsection{Within-plot variability of fruiting}

The temporal variability of fruiting in individual trees in a plot and the synchrony of fruiting between all trees in a plot was investigated in the ICP Forests dataset using the ICP Forests fruiting categories. All three fruiting categories and all plots with a minimum of 10 trees were included. We used a procedure first proposed by Herrera et al. (1998) and further refined by Buonaccorsi et al. (2003) comparing the coefficients of variation of the individual tree and the plot. To compare the level of temporal variability of fruiting between species we calculated the standard deviation of fruiting ( $\left(\mathrm{sdfr}_{i}\right.$ ) of the individual tree $i$ in the years $j$ with

$\operatorname{sdfr} r_{i}=\operatorname{sd}\left(f r_{i}\right)$

where $\mathrm{fr}_{\mathrm{i}}$ is the mean of fruiting for tree $\mathrm{i}$.

We also compared the level of temporal variability of the mean fruiting of all trees on the plot in one year, calculated with

$\operatorname{sdpfr}_{\mathrm{k}}=\operatorname{sd}\left(\mathrm{pfr}_{\mathrm{jk}}\right)$

where $\mathrm{pfr}_{\mathrm{jk}}$ is the mean of fruiting of all trees on plot $\mathrm{k}$ in the year $\mathrm{j}$.

To investigate the synchrony of fruiting of the individual trees on a plot, we calculated a Pearson's correlation coefficient $(\mathrm{r})$ between $\mathrm{fr}_{\mathrm{i}}$ and $\mathrm{pfr}_{\mathrm{jk}}$ for the individual trees on the plot. 
The analyses were carried out for the total dataset and on country level. The results were aggregated in two steps: first we calculated means per plot and tree species and secondly we averaged the plot means per tree species. We excluded trees with continuous scarce or absent fruiting. For the analysis on species level all available plots were included but only regions with at least 6 plots were analysed. The datasets from Baden-Württemberg, Bavaria and Switzerland $\mathrm{CH} 2$ and $\mathrm{CH} 3$ were not analysed as these data did not meet the requirements.

\subsection{Mast year definition on plot and regional level}

We defined fruiting years (FY) on tree level as years with common or abundant fruiting (categories 2 and 3, see section above) and category 1 (absent or scarce fruiting) as 'non-fruiting' years. For the ICP Forests data, we calculated the percentage of trees with FY for each plot and year from the treewise data.

We found little differences in spatial fruiting patterns between $30 \%$ and $80 \%$ of FY per plot (not shown) and applied a 50\% threshold to define a $\mathrm{MY}_{\text {plot }}$ at plot level. This definition was used for beech, oak species and spruce. For pine, however, this definition was adjusted as this species showed a more diffuse pattern and it was assumed that masting is not as synchronous and distinct as in other species. We therefore applied the stricter definition of $90 \%$ of all trees in a plot having a FY to count it as a MY $Y_{\text {plot }}$ (Appendix, Figs. S5 and S6). As green cones were assessed we defined the preceding year as the MY $Y_{\text {plot. }}$

The beech dataset from IAP (CH3) consists of the number of fruits per shoot. These values were translated to 0.42 fruits per shoot as a threshold for $\mathrm{MY}_{\text {plot }}$ (Braun and Flückiger 2013) which is in accordance with Paar et al. (2011) who worked with a minimum of 150 fruits per $\mathrm{m} 2$ forest floor to count a year as a MY plot. The spruce dataset from IAP $(\mathrm{CH} 3)$ consisted of fertility degree per plot and a threshold of $15 \%$ of the maximum fertility degree per plot was defined to count as MY plot. For translating the Danish values into $\mathrm{MY}_{\text {plot }} /$ non-MY $\mathrm{M}_{\text {plot, }}$ the highest annual value per plot in the dataset was defined as $100 \%$, and a 50\% threshold was applied to all annual values of this plot. $\mathrm{CH} 2$ and BW consist of stand-wise fruiting assessments with similar categories as the tree-wise assessments of ICP Forests and were categorised into $\mathrm{MY}_{\text {plot }}$ if fruiting category was 2 or 3 (common or abundant).

To define $\mathrm{MY}_{\text {region }}$ at country or regional level we tested two different approaches. MY typically show a strong increase in seed/fruit production compared to non-MY. MY region were therefore extracted according to the difference in fruit production to the previous year (method 1). As a second approach we adapted the MY definition of Curran et al. (1999). A year is counted as MYregion if the fruit/seed yield $\left(S_{\text {year }}\right)$ in one year is higher than the long-term mean $\left(S_{\text {mean }}\right)$. Based on this idea we counted a 
year as $\mathrm{MY}_{\text {region }}$ if mean mast level of all plots in one year was stronger than long-term mean mast level of all plots (method 2). For this definition we included all available years per species and region and worked with a binary code at country and regional level with $\mathrm{MY}_{\text {region }}=1$ and non-MY $\mathrm{Y}_{\text {region }}=0$.

\subsection{Mast Frequency and mast synchrony}

A mast frequency $\left(\mathrm{MF}, \mathrm{yr}^{-1}\right)$ was calculated for each tree species, plot and country or region and for different periods with

$\mathrm{MF}=(\mathrm{n}(\mathrm{MY})) / \mathrm{n}$

where $n$ is the total number of assessed years within one period and $n(M Y)$ is the number of MY among them.

In order to investigate long-term changes in masting we divided the time series into two to three periodsMF of 5 to 8 years. We then tested the differences between the periodsMF using the Wilcoxon rank test (Wonnacott and Wonnacott, 1985) with the NPAR1WAY procedure in SAS 9.3 (2014) because MF data was not normally distributed. To cover the maximum range of measured years supernumerary years between these periodsMF were left out. For plot-wise data (BadenWürttemberg, Bavaria, Switzerland $\mathrm{CH} 2$ and $\mathrm{CH} 3$ ) number of MYregion per periodMF were compared.

Mast synchrony between different regions was tested with $\chi^{2}$ tests (IBM SPSS Statistics 22) for independence for each species and between the species (Backhaus et al., 2011). For each year number of regions with MY and non-MY were counted and tested for independence between regions and species.

\section{Results}

\subsection{Synchrony of fruiting intensity of individual trees and mast year definition}

Overall, the four species groups showed a high similarity in synchrony among the temporal variation of the fruiting intensity of individual trees within a plot with $\mathrm{r}=0.78$ for beech, $\mathrm{r}=0.76$ for spruce, $r=0.65$ for oak species and $r=0.63$ for pine (table 2). In beech, there was a considerable difference between Great Britain ( $r=0.76)$ and North Rhine-Westphalia $(r=0.89)$. In the different regions the $r$ values differed considerably for spruce with a decrease in synchrony from west to east with the highest correlation in North Rhine-Westphalia ( $\mathrm{r}=0.86)$ and the lowest correlation in Estonia ( $\mathrm{r}=0.67)$. In pine, Estonia showed the lowest with $r=0.61$, whereas both parts of Norway with $r=0.64$ had slightly higher within-plot synchrony than the total pine plots. 


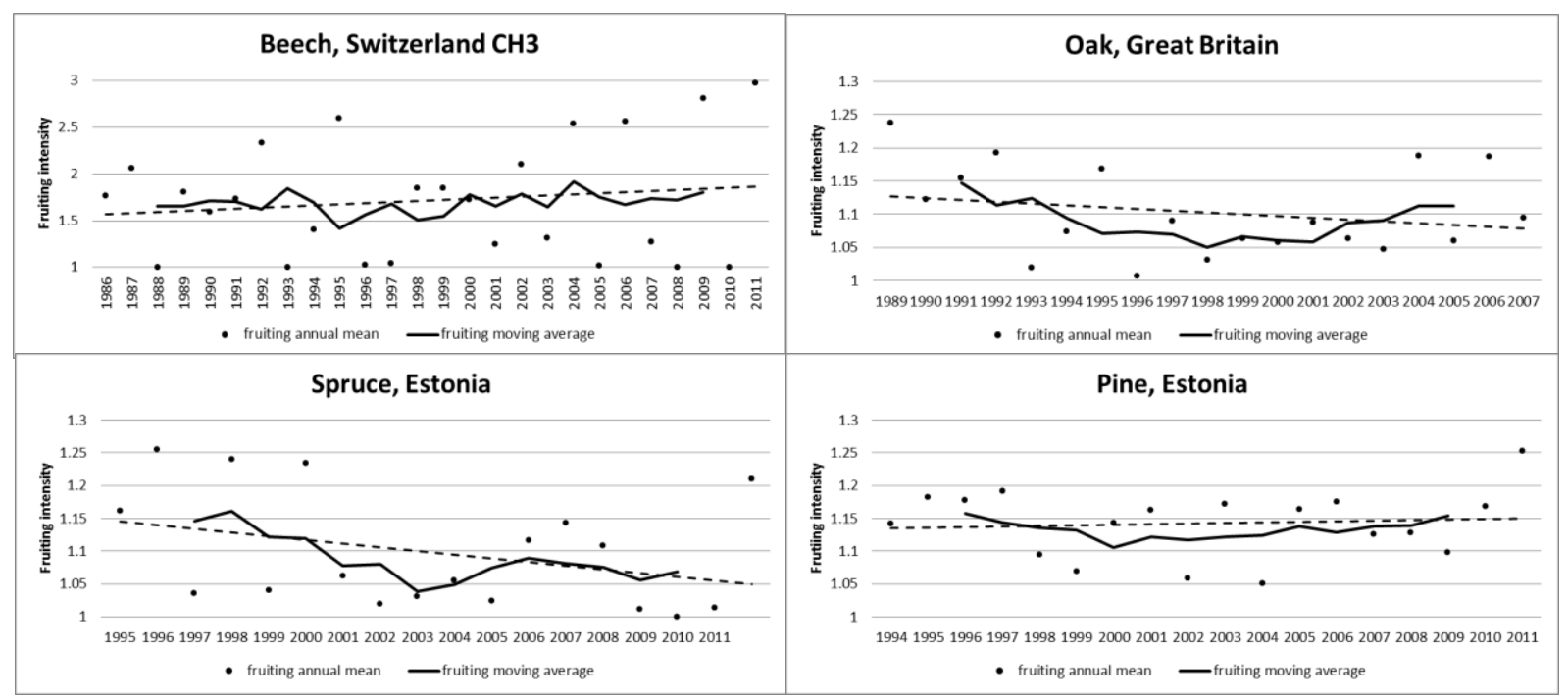

Fig. 2: Examples of changes in fruiting intensity (scale: 1 to 3) on regional level for beech in Switzerland, for oak in Great Britain and for the conifers in Estonia with moving average for 5-year periods. Linear trend lines according to fruiting intensity.

The applied threshold of 50\% for $\mathrm{MY}_{\text {region }}$ definition for the whole datasets resulted in $579 \mathrm{MY}_{\text {region }}$ and $2098 \mathrm{nMY}_{\text {region }}$ for beech, $101 \mathrm{MY}_{\text {region }}$ and $2574 \mathrm{nMY}_{\text {region }}$ for oak, $1616 \mathrm{nMY}_{\text {region }}$ and 9532 $\mathrm{nMY}_{\text {region }}$ for spruce, and the higher threshold of $90 \%$ for pine resulted the number of $\mathrm{MY}_{\text {region }}$ to 923 . Comparison of method 1 and 2 for $\mathrm{MY}_{\text {region }}$ resulted in considerable differences regarding numbers of $\mathrm{MY}_{\text {region }}($ Table S1).

\subsection{Temporal trends in mast frequency and spatial mast patterns}

\subsubsection{Common beech}

Data for beech were analysed for Great Britain, Flanders, Denmark, Switzerland (CH2 and CH3), North Rhine-Westphalia and Baden-Württemberg (fig. 2 and table 3). In most datasets, a significant increase in MF over time could be seen (Great Britain: $z=-4.9214, p<0.0001$; North RhineWestphalia: $z=-2.1717, p=0.0149$; $\mathrm{CH} 2: z=-3.6490, p<0.0001$; $\mathrm{CH} 3: z=-3.8265, p<0.0001)$, with the exceptions of Flanders and Baden-Württemberg, where there was no significant change over time, and Denmark, where a decrease was reported $(z=4.1166, p<0.0001)$. The increase of MF in North Rhine-Westphalia and in one Swiss dataset $(\mathrm{CH} 3)$ was not significant at the beginning of the time range but in the second half the increase was significant. In Denmark, the decrease in MF was significant from 2006 onward. MF was generally high with a frequency of 2.6 to 5.50 years.

Beech mast was significantly synchronous $\left(\chi^{2}=61.75, \mathrm{df}=25, \mathrm{n}=135, p<0.0001\right.$, Table $\left.\mathrm{S} 2\right)$ between the regions and there was seldom regionally isolated MY region occurrence (Table 4). 1992 was a beech $\mathrm{MY}_{\text {region }}$ in Denmark and Switzerland, with no available data from Germany. Three years later, 1995, 
there was a MYregion in Denmark, Germany, Switzerland and Great Britain. 2002 was a common MY region in Denmark, Flanders, Switzerland and Great Britain and 2004 was a MY region in Flanders, North Rhine-Westphalia, Switzerland and Great Britain, presumably as a stress reaction to the heat wave in the preceding summer. 2006, 2009 and 2011 were again MY region in almost all analysed countries, with 2011 being a 'Jahrhundertmast' (MY of the century) in Germany and Switzerland.

Table 2: Mean within-plot synchrony of temporal variation of fruiting intensity of individual trees on a plot per species (group) and country level. Pearson's correlation coefficients $r$ for correlation of fruiting intensity of individual trees in a plot and plot means.

\begin{tabular}{lccccc}
\hline Region & Pearson's $\boldsymbol{r}$ & $\boldsymbol{p}$ value & $\begin{array}{c}\text { Total number of } \\
\text { trees }\end{array}$ & $\begin{array}{c}\text { Mean number of } \\
\text { trees per plot }\end{array}$ & Number of plots \\
\hline Beech total & $0.782( \pm 0.113)$ & 0.0089 & 1775 & 22.5 & 79 \\
Great Britain & $0.760( \pm 0.116)$ & 0.0102 & 1385 & 23.5 & 59 \\
Denmark & $0.767( \pm 0.131)$ & 0.0081 & 123 & 20.5 & 6 \\
North Rhine-Westphalia & $0.890( \pm 0.095)$ & 0.0034 & 257 & 19.8 & 13 \\
\hline Oak total & $0.649( \pm 0.204)$ & 0.0652 & 1063 & 19 & 56 \\
\hline Spruce total & $0.756( \pm 0.162)$ & 0.0358 & 1513 & 15.4 & 98 \\
Switzerland CH1 & $0.727( \pm 0.167)$ & 0.0404 & 104 & 17.3 & 6 \\
North Rhine-Westphalia & $0.863( \pm 0.108)$ & 0.0106 & 134 & 19.1 & 7 \\
Estonia & $0.674( \pm 0.184)$ & 0.0792 & 82 & 13.7 & 6 \\
South Norway & $0.750( \pm 0.166)$ & 0.034 & 1022 & 15.3 & 67 \\
North Norway & $0.754( \pm 0.162)$ & 0.0363 & 171 & 14.3 & 12 \\
\hline Pine total & $0.629( \pm 0.218)$ & 0.0886 & 1281 & 14.4 & 89 \\
Estonia & $0.609( \pm 0.232)$ & 0.1096 & 557 & 16.9 & 33 \\
South Norway & $0.642( \pm 0.209)$ & 0.0753 & 334 & 11.9 & 28 \\
North Norway & $0.639( \pm 0.211)$ & 0.0785 & 352 & 14.1 & 25 \\
\hline
\end{tabular}

\subsubsection{Oak species}

Oak species were analysed for Great Britain, Flanders, Denmark and South Germany (fig. 2 and table 3). In Great Britain and Flanders there was a non-significant decrease over the assessed periods, but due to the absence of MYregion in the 1990s the increase in Great Britain from 1996-2000 to 20022006 was significant $(z=-2.6707, p=0.0038)$. In Denmark, oak species showed a significant decrease in MF from 1995 to 2013 ( $z=7.5103, p<0.0001)$, but from 2001-2006 to 2008-2013 the decrease was not significant. In Baden-Württemberg, an increase from $2 \mathrm{MY}_{\text {region }}$ in the 6-year period 1995-2000 to $3 \mathrm{MY}_{\text {region }}$ in $2008-2013$ was reported. 


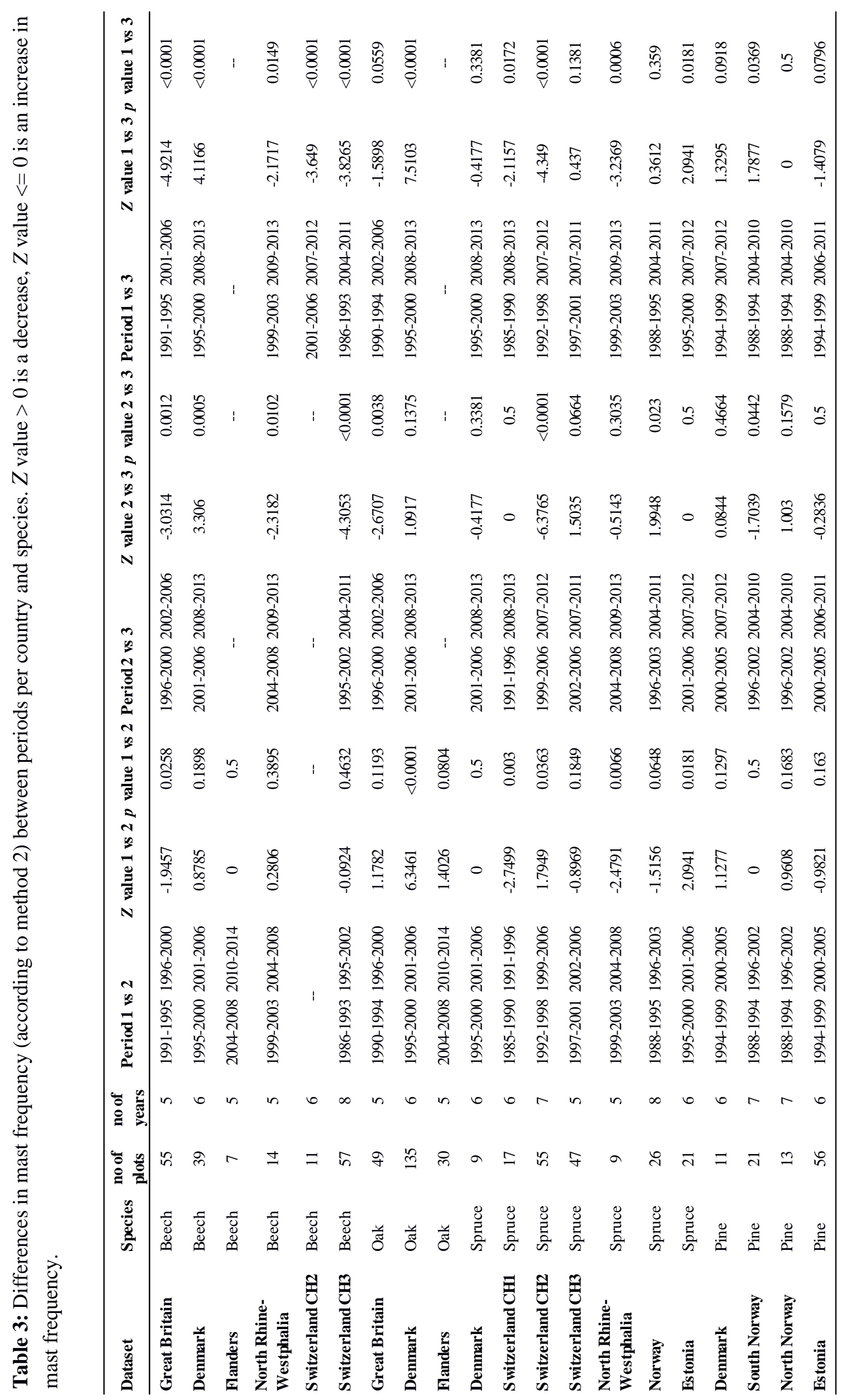


Table 4: $\mathrm{MY}_{\text {region }}$ in beech plots in European regions. $\mathbf{1}=$ mast year, $0=$ no mast year, $\mathrm{MF}=$ mast frequency, $\mathrm{n}$ of years = number of assessed years. If two values are shown, method $1 \mathrm{MY}$ definition refers to the first and method $2 \mathrm{MY}$ definition refers to the second value.

\begin{tabular}{|c|c|c|c|c|c|c|c|c|}
\hline Year & $\begin{array}{c}\text { Great } \\
\text { Britain }\end{array}$ & $\begin{array}{l}\text { Belgium } \\
\text { Flanders }\end{array}$ & Denmark & $\begin{array}{c}\text { Germany } \\
\text { NRW }\end{array}$ & $\begin{array}{c}\text { Germany } \\
\text { BW }\end{array}$ & $\begin{array}{c}\text { Germany } \\
\text { BY }\end{array}$ & $\begin{array}{c}\text { Switzerland } \\
\text { CH2 }\end{array}$ & $\begin{array}{c}\text { Switzerland } \\
\text { CH3 }\end{array}$ \\
\hline 1986 & & & & & & & & 0 \\
\hline 1987 & & & & & & & & 1 \\
\hline 1988 & & & & & & & & 0 \\
\hline 1989 & 0 & & 1 & & & & & 0 \\
\hline 1990 & 1 & & 0 & & & & & 0 \\
\hline 1991 & 0 & & 0 & & & & & 0 \\
\hline 1992 & 0 & & 1 & & & & & 1 \\
\hline 1993 & 0 & & 0 & & & & & 0 \\
\hline 1994 & 0 & & 0 & & & & & 0 \\
\hline 1995 & 1 & & 1 & & 1 & & & 1 \\
\hline 1996 & 0 & & 0 & & 0 & & & 0 \\
\hline 1997 & 0 & & 0 & & 0 & & & 0 \\
\hline 1998 & 0 & & 1 & & 0 & & & 0 \\
\hline 1999 & 0 & & 0 & 0 & 1 & 0 & & 0 \\
\hline 2000 & 1 & & 1 & 1 & 0 & 0 & & 0 \\
\hline 2001 & 0 & & 0 & 0 & 1 & 0 & 0 & 0 \\
\hline 2002 & 1 & & 1 & 1 & 0 & 0 & 0 & $0 / \mathbf{1}$ \\
\hline 2003 & 0 & & 0 & 0 & 0 & 1 & $\mathbf{1} / 0$ & $\mathbf{1} / 0$ \\
\hline 2004 & 1 & 1 & 0 & 1 & 0 & 0 & 0 & 1 \\
\hline 2005 & 0 & 0 & 0 & 0 & 0 & 0 & 0 & 0 \\
\hline 2006 & 1 & 0 & 1 & 0 & 1 & 1 & 1 & 1 \\
\hline 2007 & & 0 & 0 & 0 & 0 & 0 & 0 & 0 \\
\hline 2008 & & 0 & 0 & 0 & 0 & 0 & 0 & 0 \\
\hline 2009 & & 0 & 1 & 1 & 1 & & 1 & 1 \\
\hline 2010 & & 0 & 0 & 0 & 0 & & 0 & 0 \\
\hline 2011 & & 1 & 1 & 1 & 1 & & 1 & 1 \\
\hline 2012 & & 0 & 0 & 0 & 0 & & 0 & \\
\hline 2013 & & 0 & 0 & 0 & 0 & & 0 & \\
\hline 2014 & & 0 & 1 & & & & & \\
\hline MF & 3 & 5.5 & 2.6 & 3 & 3.17 & 5 & $3.25 / 4.33$ & 3.25 \\
\hline $\begin{array}{c}\mathrm{n} \text { of } \\
\text { years }\end{array}$ & 18 & 11 & 26 & 15 & 19 & 10 & 13 & 26 \\
\hline
\end{tabular}

Overall, oak species showed more MYregion than beech with a MF of 2.11 to 3.67 years with the exception of 6.33 years for Quercus robur in Denmark. Synchrony between regions was almost significant $\left(\chi^{2}=24.76, \mathrm{df}=18, \mathrm{n}=71, p=0.055\right.$, Table $\left.\mathrm{S} 2\right)$ and not significant for the species-wise analysis of Denmark and Baden-Württemberg ( $Q$. robur: $\chi^{2}=15.77, \mathrm{df}=18, \mathrm{n}=38, p=0.246 ; Q$. petraea: $\left.\chi^{2}=21.00, \mathrm{df}=18, \mathrm{n}=38, p=0.183\right) .2000$ and 2001 were $\mathrm{MY}_{\text {region }}$ in Denmark and South 
Germany (Table 5). 2006 and 2011 were MY region in all regions except for Denmark, where there was only one common MY region in the last decade for both oak species (2008). Q. petraea had common MY region in Denmark and Baden-Württemberg in 1998, 2000, 2001, 2005 and 2008, whereas Q. robur had only one common $\mathrm{MY}_{\text {region }}$ in Denmark and Baden-Württemberg in 2000. A regular occurrence of consecutive MY region could be found, e.g. from 1989-1992 in Great Britain or for Q. petraea from 2000-2003 in Denmark and from 2004-2006 in Baden-Württemberg.

Table 5: $\mathrm{MY}_{\text {region }}$ in oak plots in European regions. 1 = mast year, $0=$ no mast year, $\mathrm{MF}=$ mast frequency, $\mathrm{n}$ of years $=$ number of assessed years. Only method $2 \mathrm{MY}$ definition is shown.

\begin{tabular}{|c|c|c|c|c|c|c|c|c|c|}
\hline \multirow[b]{2}{*}{ Year } & \multicolumn{5}{|c|}{ Quercus spec. } & \multicolumn{2}{|c|}{ Quercus robur } & \multicolumn{2}{|c|}{ Quercus petraea } \\
\hline & $\begin{array}{c}\text { Great } \\
\text { Britain }\end{array}$ & $\begin{array}{l}\text { Belgium } \\
\text { Flanders }\end{array}$ & Denmark & $\begin{array}{c}\text { Germany } \\
\text { BW }\end{array}$ & $\begin{array}{c}\text { Germany } \\
\text { BY }\end{array}$ & Denmark & $\begin{array}{c}\text { Germany } \\
\text { BW }\end{array}$ & Denmark & $\begin{array}{c}\text { Germany } \\
\text { BW }\end{array}$ \\
\hline 1989 & 1 & & & & & & & & \\
\hline 1990 & 1 & & & & & & & & \\
\hline 1991 & 1 & & & & & & & & \\
\hline 1992 & 1 & & & & & & & & \\
\hline 1993 & 0 & & & & & & & & \\
\hline 1994 & 0 & & & & & & & & \\
\hline 1995 & 1 & & 1 & 0 & & 1 & 0 & 0 & 1 \\
\hline 1996 & 0 & & 0 & 0 & & 0 & 0 & 0 & 0 \\
\hline 1997 & 1 & & 0 & 0 & & 0 & 0 & 0 & 0 \\
\hline 1998 & 0 & & 1 & 1 & & 0 & 1 & 1 & 1 \\
\hline 1999 & 0 & & 0 & 0 & 0 & 0 & 0 & 0 & 0 \\
\hline 2000 & 0 & & 1 & 1 & 1 & 1 & 1 & 1 & 1 \\
\hline 2001 & 0 & & 1 & 1 & 1 & 0 & 1 & 1 & 1 \\
\hline 2002 & 0 & & 1 & 0 & 0 & 0 & 0 & 1 & 0 \\
\hline 2003 & 0 & & 0 & 1 & 1 & 0 & 1 & 1 & 0 \\
\hline 2004 & 1 & 0 & 0 & 0 & 0 & 0 & 0 & 0 & 1 \\
\hline 2005 & 0 & 0 & 0 & 0 & 0 & 0 & 0 & 1 & 1 \\
\hline 2006 & 1 & 1 & 0 & 1 & 1 & 0 & 1 & 0 & 1 \\
\hline 2007 & 0 & 1 & 0 & 1 & 0 & 0 & 1 & 1 & 0 \\
\hline 2008 & & 0 & 1 & 0 & 0 & 1 & 0 & 1 & 1 \\
\hline 2009 & & 0 & 0 & 1 & & 0 & 0 & 0 & 0 \\
\hline 2010 & & 0 & 0 & 0 & & 0 & 0 & 0 & 0 \\
\hline 2011 & & 1 & 0 & 1 & & 0 & 1 & 0 & 1 \\
\hline 2012 & & 0 & 0 & 1 & & 0 & 0 & 0 & 0 \\
\hline 2013 & & 0 & 0 & 0 & & 0 & 0 & 0 & 0 \\
\hline 2014 & & 0 & & & & & & & \\
\hline $\mathrm{MF}$ & 2.38 & 3.67 & 3.17 & 2.11 & 2.5 & 6.33 & 2.71 & 2.38 & 2.11 \\
\hline $\begin{array}{l}\mathrm{n} \text { of } \\
\text { years }\end{array}$ & 19 & 11 & 19 & 19 & 10 & 19 & 19 & 19 & 19 \\
\hline
\end{tabular}




\subsubsection{Norway spruce}

For spruce, Norway, Estonia, Denmark, North Rhine-Westphalia, Baden-Württemberg, Bavaria and Switzerland were analysed (fig. 2 and table 3). There were different trends in the analysed regions with no clear geographical pattern. In Baden-Württemberg and Estonia, spruce MF decreased over the last two decades (Estonia: $z=2.0941, p=0.0181$ ), but in North Rhine-Westphalia and in two Swiss datasets (CH1 and CH2) MF increased (NRW: $z=-3.2369, p=0.0006, \mathrm{CH} 1: z=-2.1157, p=0.0172$, CH2: $z=-4.3490, p<0.0001)$. In Denmark, Norway, Bavaria and in the third Swiss dataset $(\mathrm{CH} 3)$, there was no significant trend. MF variability between regions was within the same range as the deciduous species (2.25 to 6.33 years).

$\mathrm{MY}_{\text {region }}$ of spruce occurred super-regionally as well as locally (Table 6) and synchrony between regions was significant $\left(\chi^{2}=44.92, \mathrm{df}=25, \mathrm{n}=132, p<0.0001\right.$, Table S2). Four common $\mathrm{MY}_{\text {region }}, 1992$, 1995, 1998 and 2006 were reported which extended from Norway in the North to Switzerland in the South. Otherwise, two common MY region in each Central $(2003,2011)$ and Northern Europe (1996, 2004) occurred. The occurrence of local MY region, however, was common as well and consecutive $M Y_{\text {region }}$ were reported for both parts of Norway, Estonia and Switzerland.

\subsubsection{Scots pine}

Pine was analysed for Norway, Estonia, Denmark, Baden-Württemberg and Bavaria (fig. 2 and table 3). In South Norway, a significant decrease in MF over the whole time range could be found ( $z=1.7877, p=0.0369)$, although in the first half there was no trend, followed by a significant increase in $\operatorname{MF}(z=-1.7039, p=0.0442)$. In Denmark a decrease of MF could be found, but it was not significant. On the other hand, in Estonia, a non-significant increase was reported and in Baden-Württemberg, four consecutive MY region occurred in 2010-2013 which led to a strong increase in MF. MF showed great differences with a range of 1.64 years in Estonia and 10 years in Bavaria.

There was no significant synchrony for pine between different regions $\left(\chi^{2}=14.92, \mathrm{df}=19, \mathrm{n}=85\right.$, $p=0.749$, Appendix table A2). In Norway, $\mathrm{MY}_{\text {region }}$ occurred mostly regionally with only two common

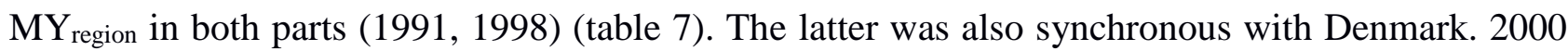
was a MY region in north Norway and Estonia. In Denmark and Baden-Württemberg, 1999, 2003, 2007 and 2009 were common MY region in pine and both regions showed a distinct pattern of consecutive mast years in 1996-1999 in Denmark, and 2001-2003 and 2007-2010 in Baden-Württemberg. Overall, pine $\mathrm{MY}_{\text {region }}$ showed less super-regional patterns than the other analysed species. 
Table 6: $\mathrm{MY}_{\text {region }}$ in spruce plots in European regions. $\mathbf{1}=$ mast year, $0=$ no mast year, $\mathrm{MF}=$ mast frequency, $\mathrm{n}$ of years = number of assessed years. Only method 2 MY definition is shown. Switzerland average $=$ average of all three datasets.

\begin{tabular}{|c|c|c|c|c|c|c|c|c|c|}
\hline Year & Norway & $\begin{array}{l}\text { Norway } \\
\text { South }\end{array}$ & $\begin{array}{l}\text { Norway } \\
\text { North }\end{array}$ & Estonia & Denmark & $\begin{array}{c}\text { Germany } \\
\text { NRW }\end{array}$ & $\begin{array}{c}\text { Germany } \\
\text { BW }\end{array}$ & $\begin{array}{c}\text { Germany } \\
\text { BY }\end{array}$ & $\begin{array}{l}\text { Switzerland } \\
\text { average }\end{array}$ \\
\hline 1985 & & & & & & & & & 0 \\
\hline 1986 & & & & & & & & & 0 \\
\hline 1987 & 1 & 0 & & & & & & & 0 \\
\hline 1988 & 0 & 0 & 0 & & & & & & 0 \\
\hline 1989 & 0 & 1 & 1 & & & & & & 0 \\
\hline 1990 & 0 & 0 & 0 & & & & & & 0 \\
\hline 1991 & & & & & & & & & 1 \\
\hline 1992 & 1 & 1 & 1 & & & & & & 1 \\
\hline 1993 & 1 & 1 & 0 & & & & & & 0 \\
\hline 1994 & 0 & 0 & 1 & & & & & & 0 \\
\hline 1995 & 1 & 1 & 1 & 1 & 0 & & 1 & & 1 \\
\hline 1996 & 0 & 0 & 1 & 1 & 0 & & 0 & & 0 \\
\hline 1997 & 0 & 0 & 0 & 0 & 0 & & 0 & & 1 \\
\hline 1998 & 1 & 1 & 1 & 1 & 1 & & 1 & & 0 \\
\hline 1999 & 0 & 0 & 0 & 0 & 0 & 0 & 0 & 0 & 0 \\
\hline 2000 & 0 & 0 & 0 & 1 & 0 & 0 & 1 & 0 & 0 \\
\hline 2001 & 0 & 0 & 0 & 0 & 0 & 0 & 0 & 0 & 0 \\
\hline 2002 & 0 & 0 & 0 & 0 & 0 & 0 & 0 & 0 & 0 \\
\hline 2003 & 0 & 0 & 0 & 0 & 0 & 0 & 1 & 1 & 1 \\
\hline 2004 & 0 & 0 & 1 & 0 & 0 & 1 & 0 & 0 & 0 \\
\hline 2005 & 0 & 0 & 0 & 0 & 0 & 0 & 0 & 0 & 0 \\
\hline 2006 & 1 & 1 & 0 & 0 & 1 & 1 & 0 & 1 & 1 \\
\hline 2007 & 0 & 1 & 0 & 0 & 0 & 0 & 0 & 0 & 0 \\
\hline 2008 & 0 & 0 & 0 & 0 & 0 & 0 & 0 & 0 & 0 \\
\hline 2009 & 0 & 0 & 0 & 0 & 0 & 0 & 0 & & 1 \\
\hline 2010 & 1 & 1 & 0 & 0 & 0 & 0 & 0 & & 0 \\
\hline 2011 & 0 & 0 & 0 & 0 & 1 & 1 & 1 & & 1 \\
\hline 2012 & 0 & 0 & 0 & 1 & 0 & 0 & 0 & & 0 \\
\hline 2013 & & & & & 0 & 0 & 0 & & 0 \\
\hline $\mathrm{MF}$ & 3.57 & 3.13 & 3.43 & 3.6 & 6.33 & 5 & 3.8 & 5 & 3.63 \\
\hline $\begin{array}{l}\mathrm{n} \text { of } \\
\text { years }\end{array}$ & 25 & 25 & 24 & 18 & 19 & 15 & 19 & 10 & 29 \\
\hline
\end{tabular}

\subsection{Inter-species synchrony}

Comparison of species per region showed no significant synchrony in any region with few exceptions (Table S3). In Bavaria, only the deciduous species were not synchronous in their mast pattern and in Denmark, although MY in beech with oak and beech with spruce were not significantly synchronous 
(beech and oak: $\chi^{2}=22.12, \mathrm{df}=18, \mathrm{n}=38, p=0.0 .075$; beech and spruce: $\chi^{2}=21.32, \mathrm{df}=18, \mathrm{n}=38$, $p=0.0 .063)$, these three species showed significant synchrony in MY $\left(\chi^{2}=22.05, \mathrm{df}=12, \mathrm{n}=51\right.$, $p=0.047)$. In Switzerland, only in one dataset ( $\mathrm{CH} 2)$ synchrony between beech and spruce was significant $\left(\chi^{2}=18.545, \mathrm{df}=16, \mathrm{n}=26, p=0.004\right)$, but in $\mathrm{CH} 3$, it was not $\left(\chi^{2}=17.892, \mathrm{df}=16, \mathrm{n}=34\right.$, $p=0.291)$.

\section{Discussion}

\subsection{Mast year definition}

Comparison of the two applied methods for MY definition revealed the complexity of this matter. For method 1 strength of increase greatly influenced the number of MYregion and was strongly dependent on the species. Method 1 only worked well in beech as this species shows a clear MY/nonMY pattern. Number of MY region in the datasets were similar with both methods. The other species often had low fruiting intensity with an absence of strong increases of fruit production or showed consecutive MY with continuously high levels of fruit crop. Method 2, the MY definition adjusted from Curran et al. (1999), might include flaws in relation to low fruiting intensity as well but is not compromised by consecutive MY.

Both methods appeared to be satisfactory for beech and could be justified by comparing our results to other records in the same regions. Our data is in accordance to the findings of Packham and Hilton (2002) for Great Britain, and our German and Swiss data are in accordance to Paar et al. (2011) who analysed beech mast behaviour in Central Germany.

For oak, method 2 resulted in a similar MF as for beech with the difference of a frequent occurrence of consecutive MY. These findings could be explained by the low fruiting intensity of a maximum of $12 \%$. The low fruit intensity might be explained by the fact that fruit development in oaks takes place later in the year than in beech (oak: September-October, beech: September) and an underestimation of fruiting intensity is plausible when assessed at the same time as beech. The low fruiting intensity in our dataset is also in contrast to other studies which describe the difference in crop size between mast failure and MY as several magnitudes (Feret et al., 1982; Gysel, 1971; Koenig et al., 1994; Sork et al., 1993). The MY definition (method 2) could not easily be evaluated due to a lack of similar studies. However, our definition did not lead to the same MY pattern as in an older study for Great Britain's oaks (Crawley and Long, 1995), where MY occurred in 1989 and 1993, whereas in our data from Great Britain, MY occurred in 1989 to 1991 but not in 1993.

For the conifers, both methods of MY definition were difficult to apply as mast intensity in spruce was low, with the exception of the Swiss CH1 dataset. For pine, MY definition seems to be inadequate 
as this species did not show a clear mast/non-mast differentiation, but produced fruits continuously on different intensity levels. Furthermore, the low within-plot synchrony revealed that MY might not be a common trait in pine.

Table 7: $\mathrm{MY}_{\text {region }}$ in pine plots in European regions. $\mathbf{1}=$ mast year, $0=$ no mast year, $\mathrm{MF}=$ mast frequency, $\mathrm{n}$ of years = number of assessed years. Only method $2 \mathrm{MY}$ definition is shown.

\begin{tabular}{|c|c|c|c|c|c|c|c|}
\hline Year & Norway & $\begin{array}{l}\text { Norway } \\
\text { South }\end{array}$ & $\begin{array}{l}\text { Norway } \\
\text { North }\end{array}$ & Estonia & Denmark & Germany BW & Germany BY \\
\hline 1986 & 0 & 0 & 0 & & & & \\
\hline 1987 & 0 & 0 & 0 & & & & \\
\hline 1988 & 0 & 0 & 0 & & & & \\
\hline 1989 & 0 & 0 & 0 & & & & \\
\hline 1990 & 1 & 1 & 0 & & & & \\
\hline 1991 & 1 & 1 & 1 & & & & \\
\hline 1992 & 0 & 0 & 0 & & & 0 & \\
\hline 1993 & 0 & 0 & 0 & & 0 & 0 & \\
\hline 1994 & 1 & 1 & 0 & 1 & 0 & 0 & \\
\hline 1995 & 1 & 0 & 0 & 1 & 0 & 1 & \\
\hline 1996 & 0 & 1 & 0 & 1 & 1 & 0 & \\
\hline 1997 & 1 & 0 & 0 & 1 & 1 & 0 & \\
\hline 1998 & 0 & 1 & 1 & 0 & 1 & 0 & 0 \\
\hline 1999 & 0 & 0 & 0 & 0 & 1 & 1 & 0 \\
\hline 2000 & 0 & 0 & 1 & 1 & 0 & 0 & 0 \\
\hline 2001 & 0 & 1 & 0 & 1 & 0 & 1 & 0 \\
\hline 2002 & 0 & 0 & 0 & 0 & 0 & 1 & 0 \\
\hline 2003 & 1 & 0 & 0 & 1 & 1 & 1 & 0 \\
\hline 2004 & 0 & 0 & 0 & 0 & 0 & 0 & 0 \\
\hline 2005 & 1 & 0 & 0 & 1 & 0 & 1 & 1 \\
\hline 2006 & 0 & 1 & 0 & 1 & 0 & 0 & 0 \\
\hline 2007 & 0 & 0 & 0 & 0 & 1 & 1 & 0 \\
\hline 2008 & 0 & 0 & 0 & 0 & 0 & 1 & \\
\hline 2009 & 0 & 0 & 0 & 0 & 1 & 1 & \\
\hline 2010 & 0 & 1 & 0 & 1 & 0 & 1 & \\
\hline 2011 & & & & 1 & 0 & & \\
\hline MF & 3.57 & 3.13 & 8.33 & 1.64 & 2.71 & 1.9 & 10 \\
\hline $\begin{array}{c}n \text { of } \\
\text { years }\end{array}$ & 25 & 25 & 25 & 18 & 19 & 19 & 10 \\
\hline
\end{tabular}




\subsection{Beech}

For beech, we found a clear pattern of MY and a high within-plot synchrony which reveals that this species shows bimodal normal masting (Kelly, 1994). These findings support the EOS of wind pollination hypothesis and furthermore is in accordance with Nielsen and De Muckadeli (1954) who found that common beech was mostly self-incompatible and therefore depends on cross pollination to produce seeds. The regular occurrence of MY in beech supports the predator satiation theory according to Kon et al. (2005b) as the change between high and low beechnut production has a strong impact on animal populations (Jenni, 1987; Tompkins et al., 2013).

Although MY did not always occur in the same years in all regions, even if these were geographically close, a tendency towards a two- to three-year mast occurrence could be seen. This pattern was most obvious in the new millennium and in Central Europe (Denmark, Germany, Switzerland). The suggestion of an underlying biennial mast pattern is therefore reasonable, as was supposed in the past by Matthews (1955) for common beech in Great Britain and by Gysel (1971) for American beech (Fagus grandiflora Ehrh.) in Michigan between 1959 and 1968. Denmark showed a slightly different pattern which could be explained by different weather phenomena such as the dry, hot summers of 2003 and 2011 in Central Europe which were not seen in Denmark (Thomsen, per comment). The regular occurrence of common MY in different regions of Europe supports the super-regional scale theory of Koenig and Knops (2000) which can also be seen in the work of Hilton and Packham (2003), who analysed European datasets from 1800 to 2001. However, the occurrence of consecutive MY as proposed by Hilton and Packham (2003) who found consecutive MY in Denmark in 1915/16, 1933/34 and 1940/41 could not be supported by our study. In contrast, our findings support the hypothesis of resource depletion by Büsgen and Münch (1929).

The findings concerning changes in MF in beech revealed different trends in the analysed regions, with mostly increases in MF in the last decade. However, there were also regions without trends or with decreases in MF over the last 20 to 30 years. We found that MF of beech increased strongly in Great Britain from 1991 to 2006, and this pattern continued between 2008-2010 (S Benham per comment). This is in contrast to Hilton and Packham (2003) who found no difference in frequency from 1930-1950 and 1980-2000 for common beech in Britain. The increase in our dataset can be explained by the exceptional occurrence of a clear biennial cycle in the early years of the new millennium, compared to only two MY in the 1990s. Similarly, in North Rhine-Westphalia and Switzerland, the increase in MY could only be seen in later years which is in accordance with the findings of Paar et al. (2011). However, they also found isolated periods of intense masting. High MF (2.6 years in 1988-2010) could also be found e.g. between 1843 and 1862. Overall the comparison of 
our results in MF changes to other studies such as Paar et al. (2011), Hilton and Packham (2003) or the dendrochronological reconstruction of a 253-year long beech mast record from Drobyshev et al. (2014) show that calculation and evaluation of this parameter is very dependent on the definition of time periods. It not only shows considerable differences between countries (e.g. in the twentieth century in Denmark, MF was higher (every 6.5 years) than in Germany (every 8.5 years) (Hilton and Packham, 2003)) but also shows substantial changes over time between high and low MF.

\subsection{Oak}

For oak, we found bimodal normal masting (Kelly, 1994) but this pattern was less pronounced than in beech and the low within-plot synchrony combined with low fruiting intensity suggests a support of the accessory costs and large seed hypotheses from Kelly (1994). Lack of within-plot synchrony may be the reason for the regular occurrence of consecutive MY which otherwise would be in direct contrast to the need for a recovery period after a fruiting year, in accordance with the resource allocation hypothesis of Büsgen and Münch (1929) and the large seed hypothesis of Sork et al. (1993). As this phenomenon also occurred in the species-wise data of Denmark and Baden-Württemberg, it seems to be a species trait rather than an artefact of analysing two species as one. Furthermore, the low within-plot synchrony does not support the EOS of wind pollination hypothesis according to Kelly (1994). A super-regional pattern as supposed by Koenig and Knops (2000) can be detected, but it was not as clear as in beech. Comparing Denmark, Great Britain, Flanders, Germany and Switzerland, it is obvious that Great Britain is not strongly synchronised with Central Europe. Comparisons of the two oak species, common and sessile oak, in Denmark and Baden-Württemberg revealed that these two species did not show similar mast behaviour, although they sometimes had common MY. These results support the findings of Crawley and Long (1995) in common and sessile oak in Great Britain and by Sork et al. (1993), who found that three North-American oak species did not show synchronised mast patterns.

Oak showed mixed trends in MF changes over the last two decades, and MF was considerably higher in our oak datasets than seen in other studies. In contrast to our results, Shaw (1974) found that sessile oak has a MF of 8 years, whereas Aldhous (1972) found a 2 to 4 year MF in common oak. Due to the high MF in oak, predator satiation strategy would work only for species which are not able to adjust their life cycle to periods of starvation.

\subsection{Spruce}

The common masting patterns in spruce was a change between annual higher or lower cone production which qualify for switching normal masting (Kelly, 1994). In combination with the regular 
occurrence of consecutive MY our findings do not support the predator satiation hypothesis. Withinplot synchrony however was high and therefore, the EOS of wind pollination hypothesis is supported by our results, but the large seed and accessory costs hypothesis were not. Like oak, Norway spruce showed consecutive MY which does not support the resource depletion theory (Büsgen and Münch, 1929).

Spruce MF was generally high and synchrony between the regions was significant. We found four synchronised MY in both North and Central Europe, and additional synchronised MY in either North or Central Europe. These findings support the suggestion by Koenig and Knops (2000) who found that conifers usually synchronise over wide regions or even on continental level. In Estonia, there were four MY in 1995-2000 but only one MY in the first decade of the new millennium. These findings are in contrast to the results of Kantorowicz (2000) who found rare MY in Poland in the second half of the 20th century. MF only increased in Central Europe in the last two decades, but in the North, a decrease or no trend could be detected. This might be evidence for two separate spruce regions (North and Central Europe) with different MY patterns.

\subsection{Pine}

For pine, we found a similar fruiting behaviour as in spruce with annually higher or lower seed production. In combination with a high amount of consecutive MY we suggest that pine shows switching normal masting (Kelly, 1994). Our findings of MY occurrence were in accordance with other studies from Great Britain (Broome et al., 2007) and Poland (Kantorowicz, 2000).

Our results with low within-plot synchrony did not support the EOS of wind pollination hypothesis and rather hinted towards the support of the accessory costs and large seed size hypotheses (Kelly, 1994), i.e. cone production, which do not require synchronised fruiting in plots. Furthermore, the frequent occurrence of consecutive MY shows that the resource depletion theory as proposed by Büsgen and Münch (1929) and the predator satiation hypothesis (Kelly, 1994) did not apply. In our datasets, synchrony was low between regions, which is in contrast to Koenig and Knops (2000) who claim that conifers usually synchronise super-regionally. Changes in MF showed mixed trends with only one significant trend (decrease) in South Norway. These overall ambiguous findings might be caused by the absence of clear MY behaviour in pine.

\subsection{Do species show synchrony with other species?}

Inter-species synchrony was generally low with the exception of Bavaria, the $\mathrm{CH} 2$ dataset and one species combination in Denmark (beech, oak, spruce). This is in contrast to earlier studies which suggest that mast seeding is not an individual trait but happens on population level and even across 
species boundaries (Fenner, 1991; Harper, 1977; Jensen, 1985; Kelly, 1994) and the suggestion of Koenig and Knops (2000) that a synchronised MY pattern would support the predator satiation theory. The lack of synchrony in MY occurrence however is in accordance with Gurnell (1993), Crawley and Long (1995) and Sork et al. (1993) who did not find synchronised MY patterns comparing different forest tree species.

\subsection{ICP Forests Level 1 network}

The datasets included in this study were received directly from the ICP Forests partners or from data collectors and supervisors from other institutions. Close contact to the data providers facilitated the validation of the data and interpretation of the results.

\section{Conclusions}

From our study we can draw the following conclusions:

The deciduous species showed bimodal normal masting and the conifers showed switching normal masting according to the definition of Kelly (1994).

We found higher within-plot synchrony of trees for beech and spruce than for oak and pine.

Elaboration of an appropriate MY definition was challenging and two methods were applied

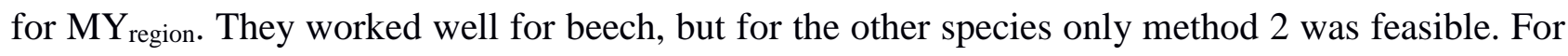
pine a MY definition was difficult to find due to the continuous fruit production in this species, and the results remain inconclusive.

Within-species mast synchrony across regions was high in beech and spruce, but oak species showed less and pine showed no synchrony. Between the oak species we could not find mast synchrony.

Mast patterns of the investigated species (groups) showed considerable synchrony between all species with the exception of pine where synchrony with other species was less strong or absent.

MF in beech increased considerably over the last 25 years in parts of Central Europe. In Flanders and Baden-Württemberg, there was no trend, and in Denmark, there was a decrease in MF for beech. MF in oak species in Great Britain and Flanders showed no significant trend, but in Denmark, there was a decrease and in Baden-Württemberg there was an increase. In the conifers MF did not change significantly in Denmark. Spruce MF decreased in Estonia and Baden-Württemberg 
and increased in Switzerland and North Rhine-Westphalia. In South Norway, there was a significant decrease in MF in pine, but the other regions showed no changes in MF over the last two decades.

\section{Acknowledgement}

We are grateful to the late Matthias Dobbertin who initiated this project. The evaluation was based on data that are part of the UNECE ICP Forests PCC Collaborative Database (see www.icpforests.net) or national databases. In particular, data from the United Kingdom (Forest Research UK), Norway (NIBIO), Estonia (Estonian Environment Agency), Denmark (IGN), North RhineWestphalia (Wald und Holz NRW), Bavaria (LWF), Switzerland (WSL) and Flanders (INBO) were part of the analyses. We gratefully received additional datasets from Baden-Württemberg (Staatsklenge Nagold, Thomas Ebinger), North Rhine-Westphalia (Landesbetrieb Wald und Holz, Kay Genau), the Principality of Liechtenstein (AfU, Markus Bernhard) and Switzerland (WSL, Anton Burkart, and IAP).

Data collection was co-financed by the European Commission under regulations (EEC) No 2158/86, Forest Focus (EC) No 2152/200 and FutMon (EC) LIFE07 ENV/D/218.

The project was further co-financed by the Swiss State Secretariat for Education, Research and Innovation (SERI C11.0140) within the Cost Action FP0903 'Climate Change and Forest Mitigation and Adaptation in a Polluted Environment' and the Leibniz Centre for Agricultural Landscape Research (ZALF).

We further thank Flurin Sutter (WSL) for support in mapping and GIS work and Christian Hug (WSL) for practical advice in crown condition survey. 


\section{References}

Aldhous, J. R. (1972). "Nursery practice," HMSO.

Backhaus, K., Erichson, B., Plinke, W., and Weiber, R. (2011). "Multivariate Analysemethoden : eine anwendungsorientierte Einführung," Springer, Berlin ; Heidelberg

Beling (1877). Über die Samenjahre der Eiche, Buche und Fichte. Monatschrift f. d. Forst- und Jagdwes., 49-81.

Braun, S., and Flückiger, W. (2013). "How is our forest?." IAP, Schönenbuch, Switzerland.

Broome, A., Hendry, S., and Peace, A. (2007). Annual and spatial variation in coning shown by the Forest Condition Monitoring Programme data for Norway Spruce, Sitka spruce, and Scots pine in Britain. Forestry 80, 17-28.

Buonaccorsi, J. P., Elkinton, J., Koenig, W., Duncan, R. P., Kelly, D., and Sork, V. (2003). Measuring mast seeding behavior: relationships among population variation, individual variation and synchrony. Journal of Theoretical Biology 224, 107-114.

Büsgen, M., and Münch, E. (1929). "The Structure and Life of Forest Trees," John Wiley and Sons Inc.,, New York, NY, USA.

Crawley, M. J., and Long, C. R. (1995). Alternate Bearing, Predator Satiation and Seedling Recruitment in Quercus Robur L. Journal of Ecology 83, 683-696.

Curran, L. M., Caniago, I., Paoli, G. D., Astianti, D., Kusneti, M., Leighton, M., Nirarita, C. E., and Haeruman, H. (1999). Impact of ElNino and logging on canopy recruitment in Borneo Science 286, 2184-2188.

Drobyshev, I., Niklasson, M., Mazerolle, M. J., and Bergeron, Y. (2014). Reconstruction of a 253year long mast record of European beechreveals its association with large scale temperature variability and nolong-term trend in mast frequencies. Agricultural and Forest Meteorology 192-193, 9-17.

Drobyshev, I., Övergaard, R., Saygin, I., Niklasson, M., Hickler, T., Karlsson, M., and Sykes, M. T. (2010). Masting behaviour and dendrochronology of European beech (Fagus sylvatica L.) in southern Sweden. Forest Ecology and Management 259, 2160-2171.

Eichhorn, J., Dammann, I., Schönfelder, E., Albrecht, M., Beck, W., and Paar, U. (2008). Assessment of drought resistance of beech exemplified by the 2003 extreme weather conditions. In "Ergebnisse angewandter Forschung zur Buche" (N. F. Versuchsanstalt, ed.), Vol. 3, pp. 109-134. Universitätsverlag Göttingen, Göttingen.

Eichhorn, J., Roskams, P., Ferretti, M., Mues, V., Szepesi, A., and Durrant, D. (2010). "Manual on methods and for harmonized sampling, assessment, monitoring and analysis of the effects of air pollution on forests." UNECE ICP Forests Programme Co-ordinating Centre, Hamburg, Germany. 
Fenner, M. (1991). Irregular seed corps in forest trees. Quarterly Journal of Forestry 85, 166-172.

Feret, P. P., Kreh, R. E., Merkle, S. A., and Oderwald, R. G. (1982). Flower abundance, premature acorn absicission, and acorn production in Quercus alba L. Botanical Gazette 143, 216-218.

Greene, D. F., and Johnson, E. A. (2004). Modelling the temporal variation in the seed production of North American trees. Canadian Journal of Forest Research 34, 65-75.

Gurnell, J. (1993). Tree Seed Production and Food Conditions for Rodents in an Oak Wood in Southern England. Forestry 66, 291-315.

Gysel, L. W. (1971). A 10-year analysis of beechnut production and use in Michigan. Journal for Wildlife management 35, 516-519.

Harper, J. L. (1977). "Population Biology of Plants," Academic Press, London.

Herrera, C. M., Jordano, P., Guitian, J., and Traveset, A. (1998). Annual Variability in Seed Production by Woody Plants and the Masting Concept: Reassessment of Principles and Relationship to Pollination and Seed Dispersal. The American Naturalist 152, 576-594.

Hilton, G. M., and Packham, J. R. (2003). Variation in the masting of common beech (Fagus sylvatica L.) in northern Europe over two centuries (1800-2001). Forestry 76, 319-328.

Hoch, G., Richter, A., and Körner, C. (2003). Non-structural carbon compounds in temperate forest trees. Plant Cell Environ 26, 1067-1081.

Janzen, D. H. (1971). Seed predation by animals. Annual Review of Ecology and Systematics 2, 465492.

Jenni, L. (1987). Mass concentrations of bramblings Fringilla montifringilla in Europe 1900-1983: their dependence upon beech mast and the effect of snow cover. Ornis Scandinavica 18, 84-94. Jensen, T. S. (1985). Seed-seed predator interactions of European beech, Fagus sylvatica and forest rodents, Clethrionomys glareolus and Apodemus flavicollis. Oikos 44, 149-156.

Kantorowicz, W. (2000). Half a century of seed years in major tree species of Poland. Silvae genetica $49,245-249$.

Kelly, D. (1994). The evolutionary ecology of mast seeding. Tree 9, 465-470.

Kelly, D., and Sork, V. L. (2002). Mast seeding in perennial plants: Why, How, Where? Annual Review of Ecology and Systematics 33, 427-447.

Koenig, W. D., and Knops, J. M. N. (2000). Patterns of Annual Seed Production by Northern Hemisphere Trees: A Global Perspective. The American Naturalist 155, 59-69.

Koenig, W. D., Mumme, R. L., Carmen, W. J., and Stanback, M. T. (1994). Acorn production by oaks in central coastal California: variation within and among years. Ecology 75, 99-109.

Kon, H., Noda, T., Terazawa, K., Koyama, H., and Yasaka, M. (2005a). Evolutionary advantages of mast seeding in Fagus crenata. Journal of Ecology 93, 1148-1155.

Kon, H., Noda, T., Terazawa, K., Koyama, H., and Yasaka, M. (2005b). Proximate factors causing 
mast seeding inFagus crenata: the effects of resource level and weather cues. Canadian Journal of Botany 83, 1402-1409.

LaMontagne, J. M., and Boutin, S. (2009). Quantitative methods for defining mast-seeding years across species and studies. Journal of Vegetation Science 20.

Lauprecht, G. (1875). Buchen- und Eichen-Samenjahre im Vergleich mit der Witterung. Zeitschr. f. Forst- u. Jagdwes. 7, 246-266.

Lindquist, B. (1931). The ecology of Scandinavian beechwoods. Svenska skogsvårdsföreningens tidskrift 29, 486-520.

Matthews, J. D. (1955). The influence of weather on the frequency of beech mast years in England. Forestry 28, 107-116.

McKone, M. J., Kelly, D., and Lee, W. G. (1998). Effect of climate change on mast-seeding species: frequency of mass flowering and escape from specialist seed predators. Global Change Biology 4, 591-596.

McShea, W. J. (2000). The influence of acorn crop on annual variation in rodent and bird populations. Ecology 81, 228-238.

Muir, G., Fleming, C. C., and Schlötterer, C. (2000). Taxonomy: Species status of hybridizing oaks. Nature 405, 1016-1016.

Nielsen, P. C., and De Muckadeli, M. S. (1954). Flower observations and controlled pollinations in Fagus. Silvae genetica 3, 6-17.

Nilsson, S. G., and Wastljung, U. (1987). Seed predation and cross-pollination in mast-seeding beech (Fagus sylvatica) patches. Ecology 68, 260-265.

Ostfeld, R. S. (2013). Ecology of Lyme Disease. 243-251.

Overgaard, R., Gemmel, P., and Karlsson, M. (2007). Effects of weather conditions on mast year frequency in beech (Fagus sylvatica L.) in Sweden. Forestry 80, 555-565.

Paar, U., Guckland, A., Dammann, I., Albrecht, M., and Eichhorn, J. (2011). Häufigkeit und Intensität der Fruktifikation der Buche. AFZ-Der Wald 6, 26-29.

Packham, J. R., and Hilton, G. M. (2002). Inter- and intra-site variation in the fruiting of common beech (Fagus sylvatica L.) in England over a twenty two year period (1980-2001). Arboricultural Journal 26, 1-22.

Peters, V. S., Macdonald, S. E., and Dale, M. R. T. (2005). The interaction between masting and fire is key to white spruce regeneration. Ecology 86, 1744-1750.

Picard, J. F., Oleffe, P., and Boisaubert, B. (1991). Influence of oak mast on feeding behaviour of red deer (Cervus elaphus L). Annals of Forest Science 48, 547-559.

Rohmeder, E. (1972). "Das Saatgut in der Forstwirtschaft," Paul Parey, Hamburg, Berlin, Germany. Schnurr, J. L., Ostfeld, R. S., and Canham, C. D. (2002). Direct and indirect effects of masting on 
rodent populations and tree seed survival. Oikos 96, 402-410.

Schwappach, A. (1895). Die Samenproduktion der wichtigsten Waldholzarten in Preussen. Zeitschr. f. Forst- u. Jagdwes. 27, 147-174.

Selås, V. (1997). Cyclic Population Fluctuations of Herbivores as an Effect of Cyclic Seed Cropping of Plants:The Mast Depression Hypothesis. Nordic Society Oikos 80, 257-268.

Shaw, M. W. (1974). The reproductive characteristics of oak. In "The British oak" (M. G. Morris and F. H. Perring, eds.), pp. 162-181. Classey, Faringdon.

Silvertown, J. W. (1980). The evolutionary ecology of mast seeding in trees. Biological Journal of the Linnean Society 14, 235-250.

Smith, C. C., Hamrick, J. L., and Kramer, C. L. (1990). The Advantage of Mast Years for Wind Pollination. The American Naturalist 136, 154-166.

Solberg, S., Dobbertin, M., Reinds, G. J., Lange, H., Andreassen, K., Fernandez, P. G., Hildingsson, A., and de Vries, W. (2009). Analyses of the impact of changes in atmospheric deposition and climate on forest growth in European monitoring plots: A stand growth approach. Forest Ecology and Management 258, 1735-1750.

Sork, V. L., Bramble, J., and Sexton, O. (1993). Ecology of mast-fruiting in three species of North American deciduous oaks. Ecology 74, 528-541.

Tachiki, Y., and Iwasa, Y. (2013). Coevolution of mast seeding in trees and extended diapause of seed predators. Journal of Theoretical Biology 339, 129-139.

Tompkins, D. M., Byrom, A. E., and Pech, R. P. (2013). Predicted responses of invasive mammal communities to climate-related changes in mast frequency in forest ecosystems. Ecological Applications 23, 1075-1085.

Vapalahti, O., Mustonen, J., Lundkvist, Å., Henttonen, H., Plyusnin, A., and Vaheri, A. (2003). Hantavirus Infections in Europe. The Lancet Infectious Diseases 3, 653-661.

Wonnacott, R., and Wonnacott, T. (1985). "Introductory statistics," Wiley, New York. 


\section{Appendix}

\section{Additional datasets}

An additional dataset from Denmark with mast data was included, combining crown condition assessment and data from the Danish AgriFish Agency and the Danish Nature Agency on seed harvest volumes (tons) per year on country and stand level. As an addition to the ICP Forests Level I dataset in Switzerland (dataset CH1), we included fruiting assessment data on stand level from two sources. One dataset was collected by Anton Burkart from WSL (Swiss Federal Institute for Forest, Snow and Landscape Research, dataset CH2), the other by the IAP (Institute for Applied Plant Biology, dataset $\mathrm{CH} 3$ ). Another dataset stems from the forest seed centre in Baden-Württemberg (Staatsklenge Nagold) and consists of regional estimations of mast levels. A dataset from Flanders, Belgium, was included which covers data for beech and oak species on a $4 \times 4 \mathrm{~km}^{2}$ grid.

\section{Maps}

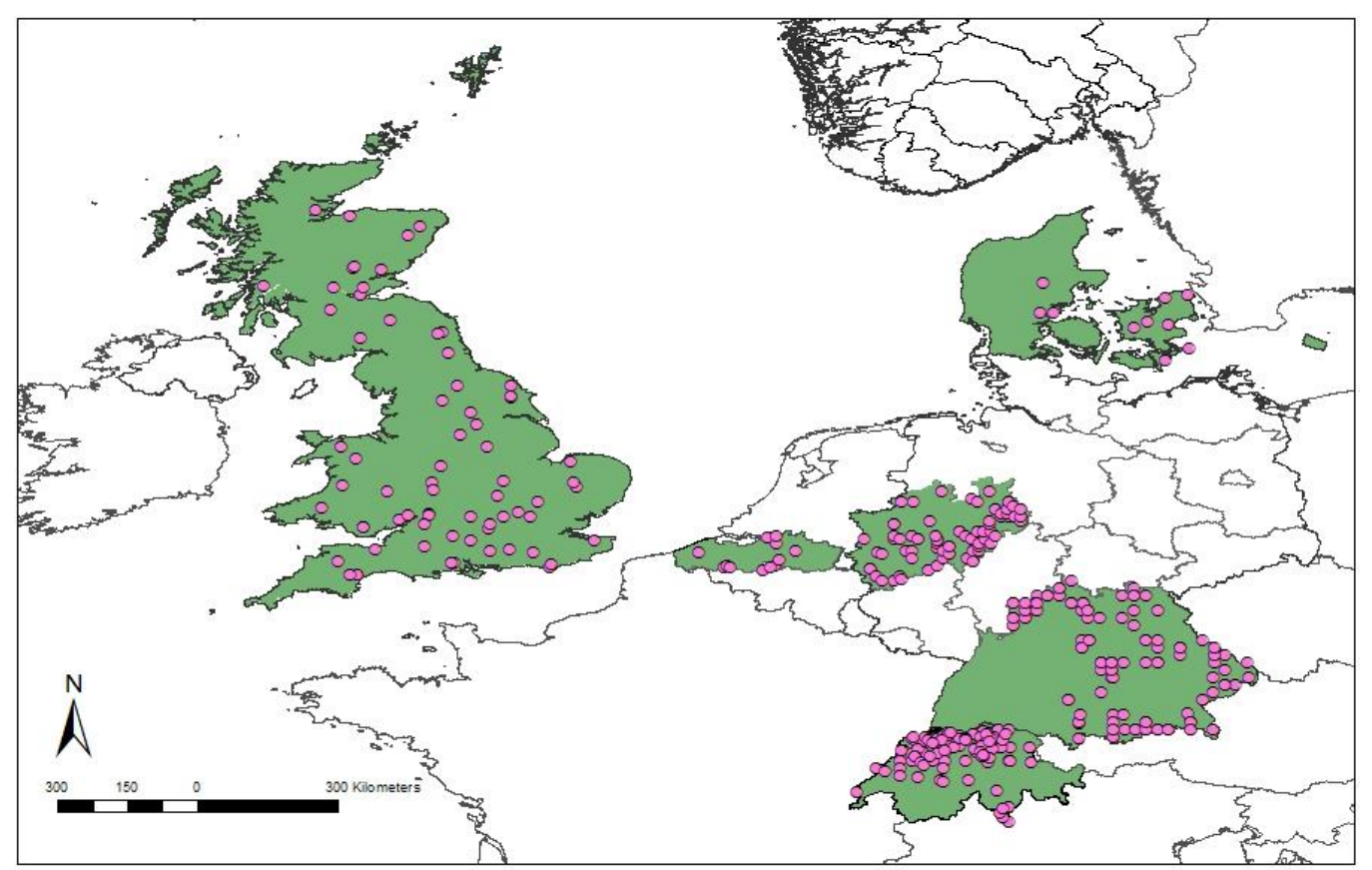

Fig. A1: Analysed beech plots and regions in Central Europe. 


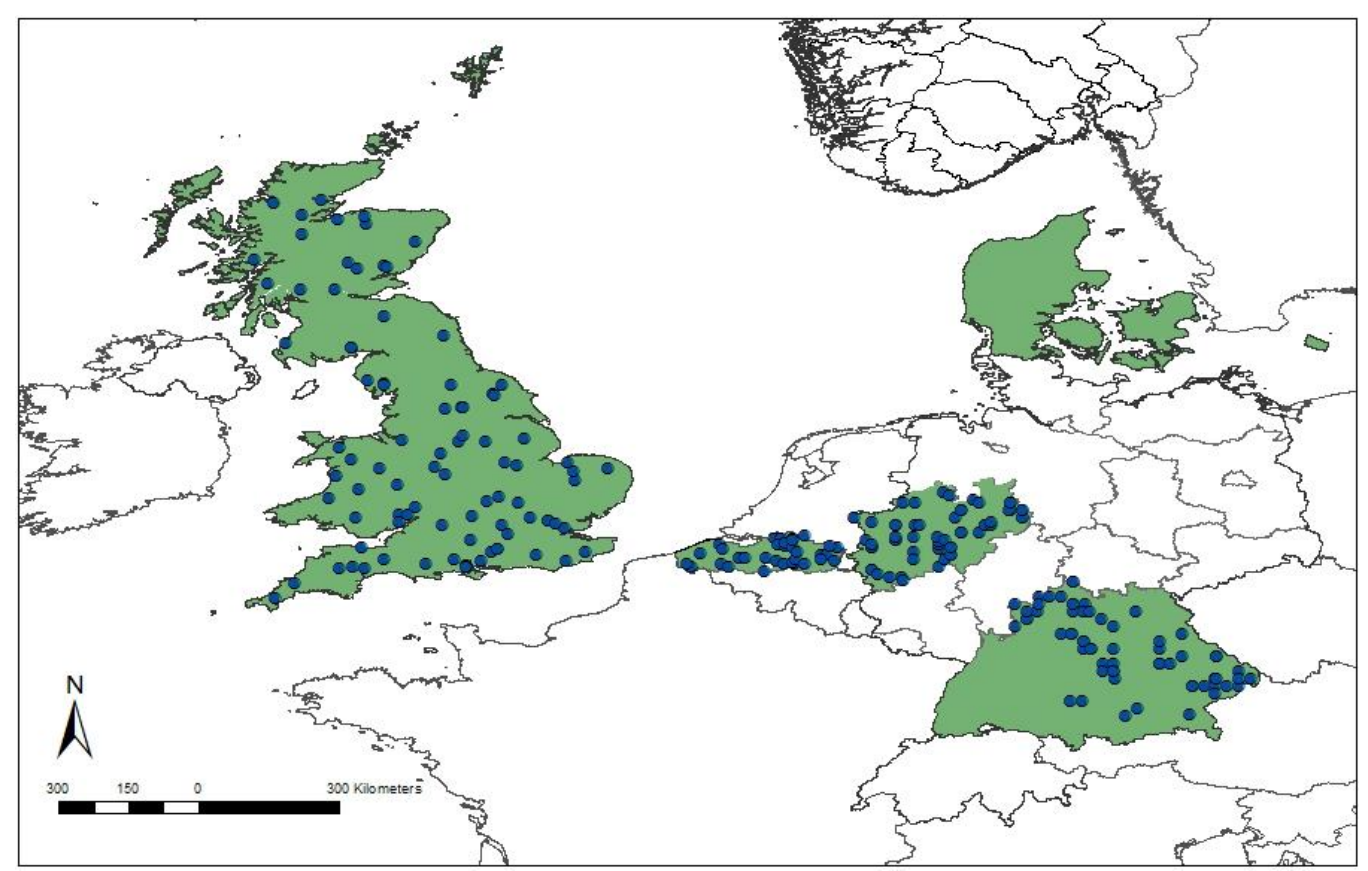

Fig. A2: Analysed oak plots and regions in Central Europe.

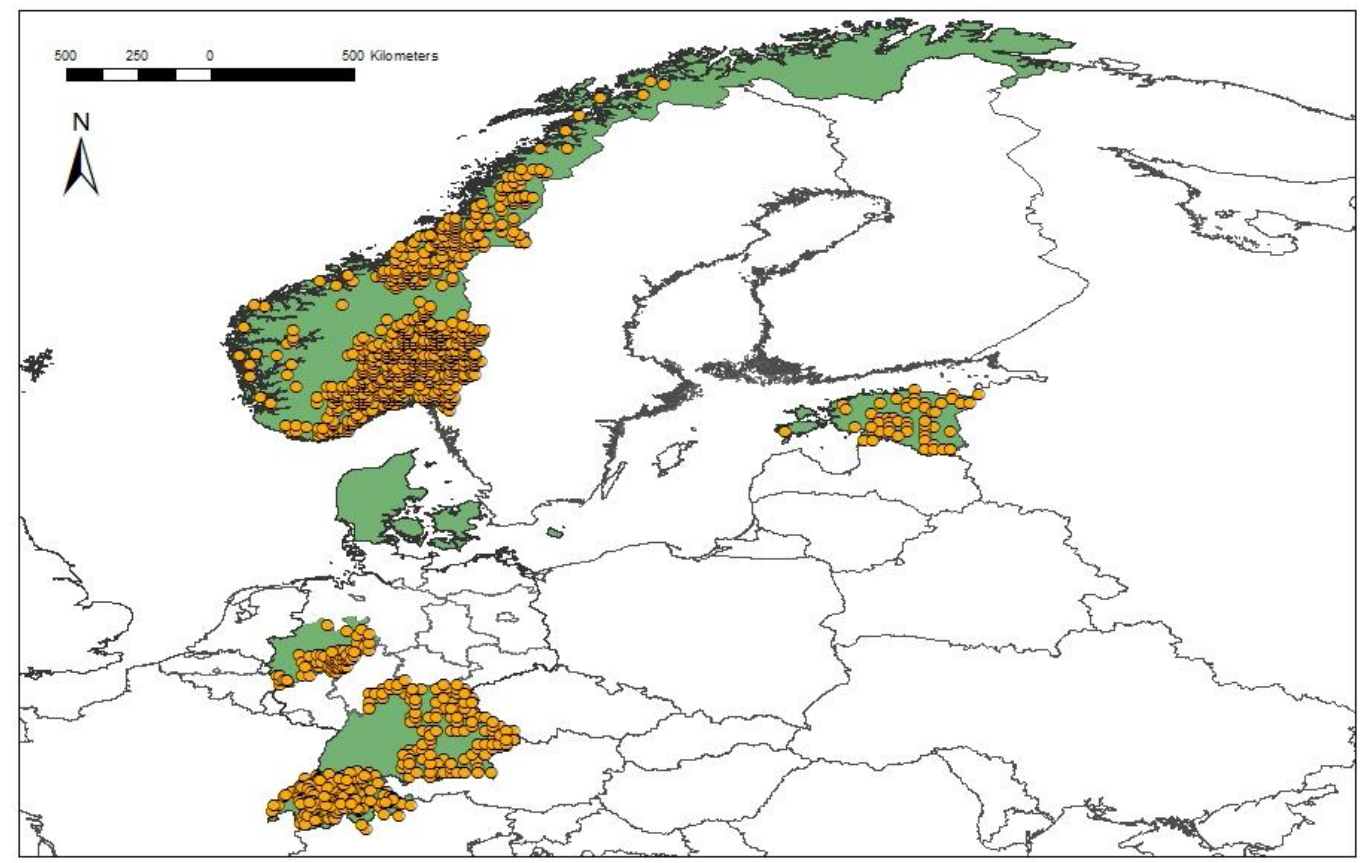

Fig. A3: Analysed spruce plots and regions in Central and Northern Europe. 


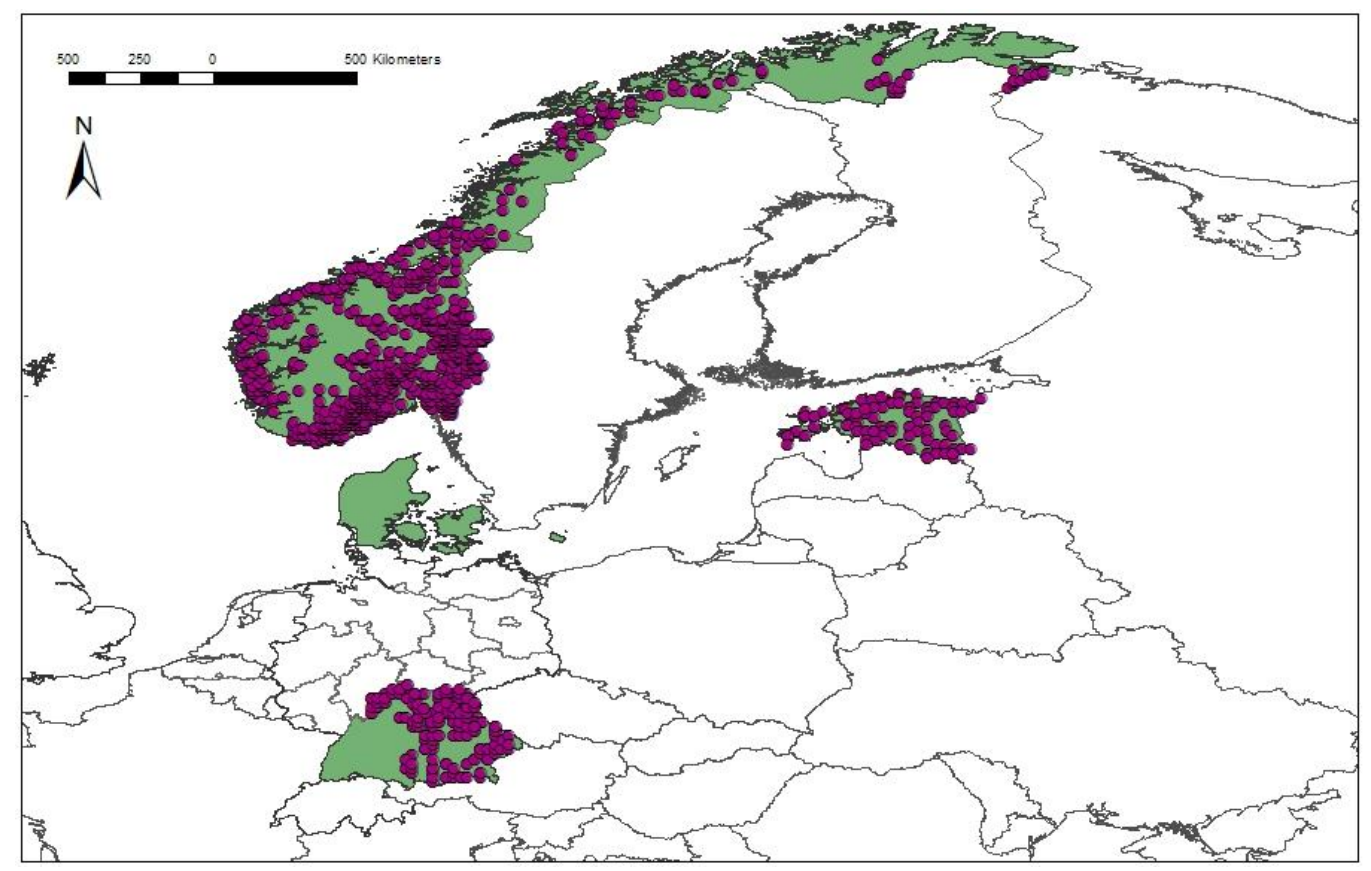

Fig. A4: Analysed pine plots and regions in Central and Northern Europe. 


\section{Comparison of MY definition}

In table A1 method 1 with three fruiting increase levels is compared to method 2. Figures A5 and A6 show differences in $\mathrm{MY}_{\text {plot }}$ patterns in pine with a threshold of $50 \%$ and $90 \%$ for $\mathrm{MY}_{\text {plot }}$ definition.

Table A1: Comparison of the two applied methods for MY definition on regional level. IL = increase level

\begin{tabular}{|c|c|c|c|c|c|c|}
\hline \multirow[t]{2}{*}{ Region } & \multirow[t]{2}{*}{ Species } & \multirow[t]{2}{*}{$\begin{array}{l}\text { Total } \\
\text { years }\end{array}$} & \multicolumn{4}{|l|}{$\begin{array}{l}\text { Number of } \\
\text { MY }\end{array}$} \\
\hline & & & $\begin{array}{l}\text { Method } 1 \\
\text { IL =0.2 }\end{array}$ & $\begin{array}{l}\text { Method } 1 \\
\text { IL=0.5 }\end{array}$ & $\begin{array}{l}\text { Method } 1 \\
\text { IL=1.0 }\end{array}$ & Method 2 \\
\hline Great Britain & Beech & 18 & 8 & 6 & 3 & 7 \\
\hline Flanders & Beech & 10 & 3 & 0 & 0 & 2 \\
\hline North Rhine-Westphalia & Beech & 15 & 6 & 4 & 1 & 4 \\
\hline Switzerland $\mathrm{CH} 2$ & Beech & 13 & 6 & 6 & 4 & 5 \\
\hline Switzerland CH3 & Beech & 26 & 12 & 9 & 5 & 8 \\
\hline Great Britain & Oak & 19 & 0 & 0 & 0 & 7 \\
\hline Flanders & Oak & 10 & 0 & 0 & 0 & 3 \\
\hline Switzerland CH1 & Spruce & 20 & 7 & 3 & 0 & 8 \\
\hline Switzerland $\mathrm{CH} 2$ & Spruce & 24 & 11 & 7 & 5 & 7 \\
\hline Switzerland CH3 & Spruce & 17 & 6 & 5 & 0 & 8 \\
\hline South Norway & Spruce & 25 & 6 & 1 & 0 & 8 \\
\hline North Norway & Spruce & 24 & 3 & 0 & 0 & 7 \\
\hline Estonia & Spruce & 18 & 0 & 0 & 0 & 5 \\
\hline North Rhine-Westphalia & Spruce & 15 & 3 & 1 & 1 & 3 \\
\hline South Norway & Pine & 25 & 1 & 0 & 0 & 13 \\
\hline North Norway & Pine & 25 & 2 & 0 & 0 & 12 \\
\hline Estonia & Pine & 18 & 0 & 0 & 0 & 11 \\
\hline
\end{tabular}




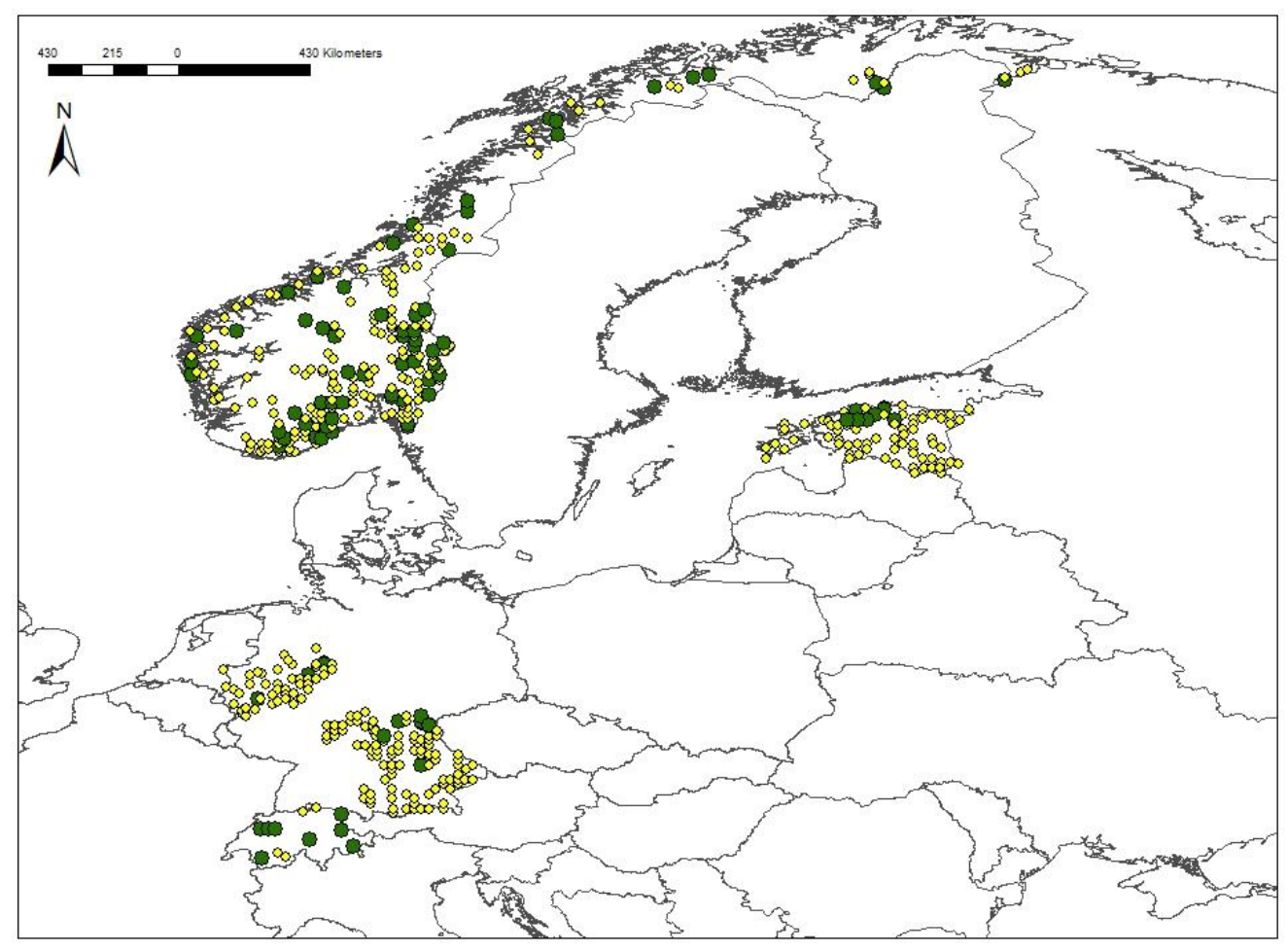

Fig. A5: Pine $\mathrm{MY}_{\text {plot }}$ with 50\% threshold applied.

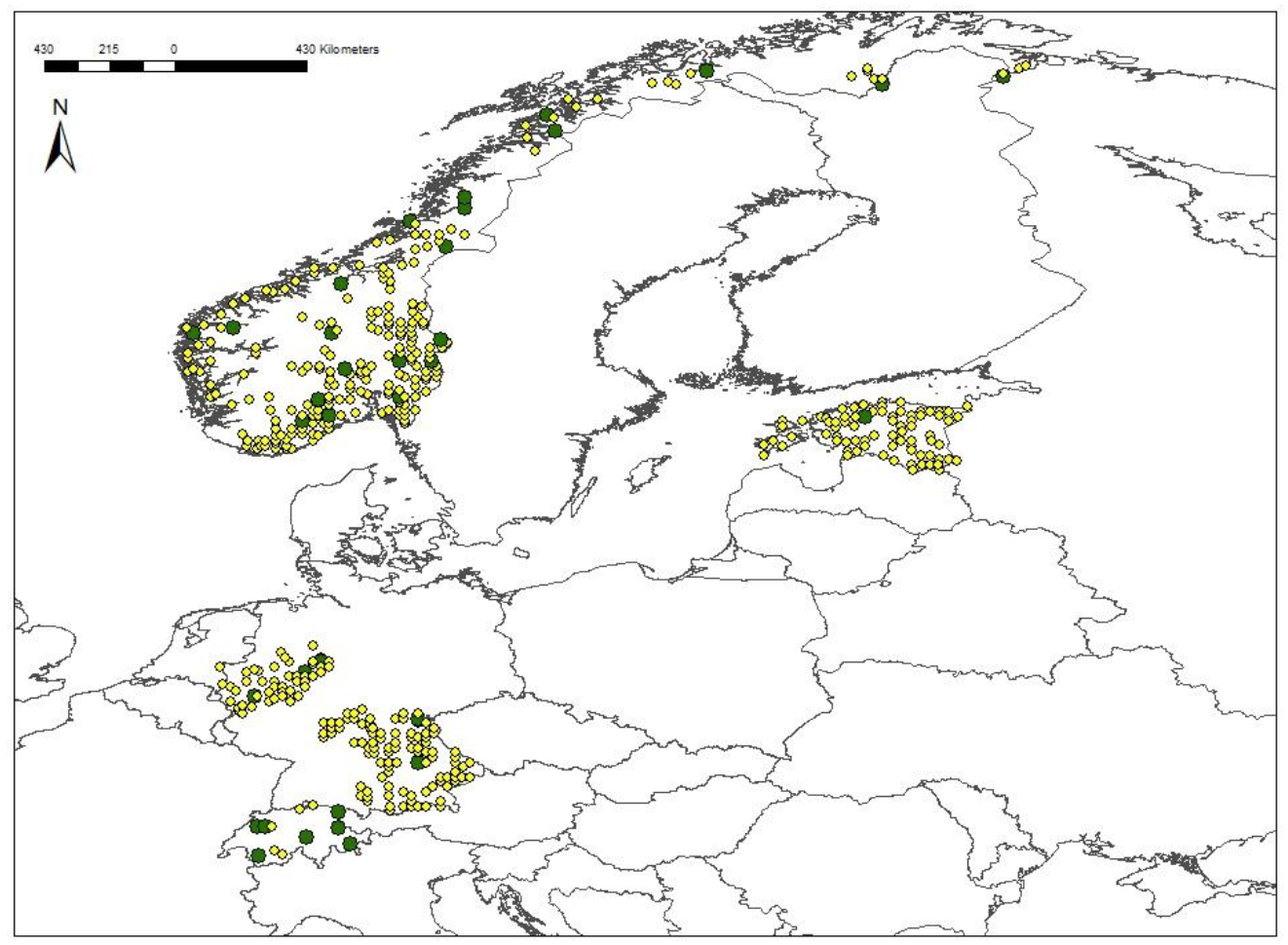

Fig. A6: Pine $\mathrm{MY}_{\text {plot }}$ with 90\% threshold applied. 


\section{4. $\chi^{2}$ test results}

Table A2: Within-species comparison between MY and non-MY in different regions. $\chi^{2}$ values within and between species. $\chi^{2}$ and $p$ values are from Fisher's exact test.

\begin{tabular}{lcccccc} 
Species & $\chi^{2}$ & $\begin{array}{c}\text { Degrees of } \\
\text { freedom }\end{array}$ & $\boldsymbol{p}$ value & $\begin{array}{c}\text { Total of } \\
\text { observations }\end{array}$ & Cramér's V & $\begin{array}{c}\text { Analysed } \\
\text { period }\end{array}$ \\
\hline Beech & 61.752 & 25 & $<\mathbf{0 . 0 0 0 1}$ & 135 & 0.727 & $1995-2013$ \\
Oak & 24.758 & 18 & 0.055 & 71 & 0.621 & $1995-2013$ \\
Spruce & 44.919 & 25 & $<\mathbf{0 . 0 0 0 1}$ & 132 & 0.642 & $1995-2013$ \\
Pine & 14.919 & 19 & 0.749 & 85 & 0.433 & $1993-2010$ \\
Q. robur BW/DK & 15.771 & 18 & 0.246 & 38 & 0.676 & $1995-2013$ \\
Q. petraea BW/DK & 21.002 & 18 & 0.183 & 38 & 0.792 & $1995-2013$ \\
\hline
\end{tabular}

Table A3: and inter-species comparison per region between MY and non-MY. $\chi^{2}$ values within and between species. $\chi^{2}$ and $p$ values are from Fisher's exact test.

\begin{tabular}{|c|c|c|c|c|c|c|}
\hline Region /species & $\chi^{2}$ & $\begin{array}{c}\text { Degrees of } \\
\text { freedom }\end{array}$ & $p$ value & $\begin{array}{c}\text { Total of } \\
\text { observations }\end{array}$ & Cramér's V & $\begin{array}{c}\text { Analysed } \\
\text { period }\end{array}$ \\
\hline NO spruce, pine & 18.004 & 22 & 0.908 & 46 & 0.641 & $1987-2010$ \\
\hline SNO spruce, pine & 22.234 & 22 & 0.428 & 46 & 0.745 & $1987-2010$ \\
\hline NNO spruce, pine & 19.126 & 21 & 0.641 & 44 & 0.715 & $1988-2010$ \\
\hline EE spruce, pine & 19.199 & 24 & 1 & 50 & 0.625 & $1995-2011$ \\
\hline DK beech, oak & 22.124 & 18 & 0.075 & 38 & 0.841 & $1995-2013$ \\
\hline DK beech, spruce & 21.316 & 18 & 0.063 & 38 & 0.824 & $1995-2013$ \\
\hline DK beech, pine & 13.269 & 16 & 0.901 & 34 & 0.627 & $1995-2013$ \\
\hline DK oak, spruce & 16.292 & 18 & 0.710 & 38 & 0.7 & $1995-2013$ \\
\hline DK oak, pine & 11.477 & 16 & 0.979 & 34 & 0.561 & $1995-2013$ \\
\hline DK spruce, pine & 13.783 & 16 & 0.848 & 34 & 0.544 & $1995-2013$ \\
\hline DK beech, oak, spruce & 22.046 & 16 & 0.047 & 51 & 0.725 & $1995-2013$ \\
\hline DK beech, oak, pine & 14.192 & 16 & 0.729 & 51 & 0.536 & $1995-2013$ \\
\hline DK beech, spruce, pine & 16.393 & 16 & 0.458 & 51 & 0.594 & $1995-2013$ \\
\hline DK oak, spruce, pine & 11.06 & 18 & 0.955 & 51 & 0.825 & $1995-2013$ \\
\hline DK all & 16.739 & 16 & 0.381 & 68 & 0.511 & $1995-2013$ \\
\hline GB beech, oak & 20.088 & 17 & 0.182 & 36 & 0.806 & 1989-2006 \\
\hline FL beech, oak & 10.68 & 10 & 0.439 & 22 & 0.782 & 2004-2014 \\
\hline NRW beech, spruce & 15.74 & 14 & 0.226 & 30 & 0.812 & 1999-2013 \\
\hline
\end{tabular}


Table A3: continued

\begin{tabular}{|c|c|c|c|c|c|c|}
\hline Region /species & $\chi^{2}$ & $\begin{array}{l}\text { Degrees of } \\
\text { freedom }\end{array}$ & $p$ value & $\begin{array}{c}\text { Total of } \\
\text { observations }\end{array}$ & Cramér's V & $\begin{array}{c}\text { Analysed } \\
\text { period }\end{array}$ \\
\hline BW beech, oak & 20.376 & 18 & 0.259 & 38 & 0.784 & $1995-2013$ \\
\hline BW beech, spruce & 17.965 & 18 & 0.478 & 38 & 0.743 & $1995-2013$ \\
\hline BW beech, pine & 16.264 & 15 & 0.454 & 32 & 0.749 & $1995-2010$ \\
\hline BW oak, spruce & 21.298 & 18 & 0.149 & 32 & 0.813 & $1995-2013$ \\
\hline BW oak, pine & 13.491 & 15 & 0.817 & 32 & 0.66 & $1995-2010$ \\
\hline BW spruce, pine & 11.918 & 15 & 0.933 & 32 & 0.604 & $1995-2010$ \\
\hline BW beech, oak, spruce & 24.205 & 18 & 0.064 & 57 & 0.697 & $1995-2013$ \\
\hline BW beech, oak, pine & 17.337 & 15 & 0.333 & 48 & 0.62 & $1995-2010$ \\
\hline BW beech, spruce, pine & 13.973 & 15 & 0.663 & 48 & 0.551 & $1995-2010$ \\
\hline BW oak, spruce, pine & 14.862 & 15 & 0.580 & 48 & 0.568 & $1995-2010$ \\
\hline BW all & 17.52 & 15 & 0.297 & 64 & 0.536 & $1995-2010$ \\
\hline BY beech, oak & 11.927 & 9 & 0.133 & 20 & 0.873 & $1998-2007$ \\
\hline BY beech, spruce & 12.988 & 9 & 0.009 & 20 & 1 & 1998-2007 \\
\hline BY beech, pine & 10.751 & 9 & 0.158 & 20 & 0.897 & $1998-2007$ \\
\hline BY oak, spruce & 11.927 & 9 & 0.809 & 20 & 0.873 & $1998-2007$ \\
\hline BY oak, pine & 9.728 & 9 & 0.480 & 20 & 0.775 & $1998-2007$ \\
\hline BY spruce, pine & 10.751 & 9 & 0.001 & 20 & 0.897 & $1998-2007$ \\
\hline BY beech, oak, spruce & 17.332 & 9 & 0.002 & 30 & 0.879 & $1998-2007$ \\
\hline BW beech, oak, pine & 13.824 & 9 & 0.036 & 30 & 0.792 & $1998-2007$ \\
\hline BY beech, spruce, pine & 15.178 & 9 & 0.002 & 30 & 0.917 & 1998-2007 \\
\hline BY oak, spruce, pine & 13.824 & 9 & 0.036 & 30 & 0.792 & 1998-2007 \\
\hline BY all & 19.539 & 9 & 0.001 & 40 & 0.823 & $1998-2007$ \\
\hline $\mathrm{CH} 2$ beech, spruce & 18.545 & 12 & 0.004 & 26 & 0.957 & 2001-2013 \\
\hline $\mathrm{CH} 3$ beech, spruce & 17.892 & 16 & 0.291 & 34 & 0.783 & $1995-2011$ \\
\hline
\end{tabular}

